NBER WORKING PAPER SERIES

\title{
BENEFITS AND SPILLOVERS OF \\ GREATER COMPETITION IN EUROPE: A MACROECONOMIC ASSESSMENT
}

\author{
Tamim Bayoumi \\ Douglas Laxton \\ Paolo Pesenti \\ Working Paper 10416 \\ http://www.nber.org/papers/w10416
}

\author{
NATIONAL BUREAU OF ECONOMIC RESEARCH \\ 1050 Massachusetts Avenue \\ Cambridge, MA 02138 \\ April 2004
}

We are indebted to Lawrence Christiano, Jerome Henry, and David Reifschneider for sharing data and simulation results. We thank Ignazio Angeloni, Gôunter Coenen, Dale Henderson, Patrick Minford, Assaf Razin, Ken RogoP, Stefano Scarpetta, Mike Woodford and seminar participants at the II International Research Forum on Monetary Policy at the Federal Reserve Board of Governors, the Bank of Finland, the Bank of Canada, the Nederlandsche Bank, Cornell University and the University of Houston for comments and suggestions. The views expressed here are those of the authors, and do not necessarily reàect the position of the International Monetary Fund, the Federal Reserve Bank of New York, the Federal Reserve System, or any other institution with which the authors are affiliated. Correspondence: tbayoumi@imf.org; dlaxton@imf.org; paolo.pesenti@ny.frb.org. The views expressed herein are those of the author(s) and not necessarily those of the National Bureau of Economic Research.

(C2004 by Tamim Bayoumi, Douglas Laxton, Paolo Pesenti. All rights reserved. Short sections of text, not to exceed two paragraphs, may be quoted without explicit permission provided that full credit, including (C) notice, is given to the source. 
Benefits and Spillovers of Greater Competition in Europe: A Macroeconomic Assesment Tamim, Bayoumi, Douglas Laxton, and Paolo Pesenti

NBER Working Paper No. 10416

April 2004

JEL No. C51, E31, E52

\section{$\underline{\text { ABSTRACT }}$}

Using a general-equilibrium simulation model featuring nominal rigidities and monopolistic competition in product and labor markets, this paper estimates the macroeconomic benefits and international spillovers of an increase in competition. After calibrating the model to the euro area vs. the rest of the industrial world, the paper draws three conclusions. First, greater competition produces large effects on macroeconomic performance, as measured by standard indicators. In particular, we show that differences in competition can account for over half of the current gap in GDP per capita between the euro area and the US. Second, it may improve macroeconomic management by increasing the responsiveness of wages and prices to market conditions. Third, greater competition can generate positive spillovers to the rest of the world through its impact on the terms of trade.

Tamim Bayoumi International Monetary Fund

Washington, DC 20431

tbayoumi@imf.org

Douglas Laxton International Monetary Fund

Washington, DC 20431

dlaxton@imf.org

Paolo Pesenti

Federal Reserve Bank of New York

33 Liberty Street

New York, NY 10045

paolo.pesenti@ny.frb.org 


\section{Introduction}

Why are there such large differences in income per capita across countries, both within the industrial core and between this core and the rest of the world? For much of the postwar period, the standard answer to this question focused on the process of technological catch-up. More recently, however, it is becoming increasingly clear that structural differences across countries play a key role, both directly and by providing impediments to the successful implementation of macroeconomic policies. ${ }^{1}$ This switch in emphasis is particularly evident in continental Europe, where the leading explanation of the continuing divergence in material wealth from that of the United States is that labor and product markets are more hampered by regulations than their U.S. counterparts. ${ }^{2}$ Indeed, the action plans endorsed in a series of recent summits of European leaders suggests that increasing competition in Europe through deregulation has become a major policy priority. ${ }^{3}$ Despite the importance of this topic, however, estimates of the benefits from greater competition are limited. ${ }^{4}$

This paper uses a general equilibrium model to estimate the effects of changing competition on performance within a country and spillovers to the rest of the world. Specifically, the model posits imperfect competition in product and labor markets which drives a wedge between the true marginal cost/product and actual prices/wages. These markups are inversely related to the degree of substitutability across goods/inputs, and hence the underlying level of competition. ${ }^{5}$ A two-country setup involving the euro area and the rest of the world -

\footnotetext{
${ }^{1}$ See MacFarlan, Edison, and Spatafora (2003) for a survey. Key references include Hall and Jones (1999) and Acemoglu, Johnson, and Robinson (2002). Prescott (2003) stresses the role of tax asymmetries in accounting for differences in labor supply across time and across countries.

${ }^{2}$ For a recent assessment of the extent of regulation in Europe, as well as the reform process in labor and product markets, see Blanchard (2004).

${ }^{3}$ Such summits have been held in Luxembourg, Cologne, Cardiff, Lisbon (twice), and Barcelona. See Baily (2003) for a detailed analysis.

${ }^{4}$ Earlier work includes OECD (1997) and European Commission (2002).

${ }^{5}$ See Woodford (2003), Part I, and its references for an introduction to the literature.
} 
where the calibration of the latter is based on the United States - is used to explore how altering domestic competition in labor and product markets affects performance at home and abroad across a wide range of elasticities/markups and other key parameters in the model. Empirical estimates of euro area and U.S. markups are then used to estimate the impact of increasing competition in the euro area to levels prevailing in the United States.

Anticipating our conclusions, we find that increasing competition leads to sizable increases in domestic output and consumption, as well as easing the task of the monetary authorities by reducing the distortions associated with wage-price rigidities. These benefits also provide positive spillovers to the rest of the world, mainly through a favorable terms of trade effect which boosts consumption abroad by more than output.

Indeed, our estimates of the potential long-term gains from greater competition in the euro area are substantial, and would greatly diminish the difference in material well-being between the euro area and the United States. Our simulations indicate that increasing competition in the euro area to U.S. levels could boost output by 12.4 percent in the euro area as both investment and hours worked rise markedly, and by 0.8 percent in the rest of the world. The consumption benefits are more evenly spread, with euro area consumption rising 8.3 percent versus 1.3 percent elsewhere. In addition, monetary policy becomes more effective in the euro area, as the sacrifice ratio (i.e. the cost in foregone output required to reduce inflation by 1 percent) declines significantly. These benefits come about because greater competition reduces the monopolistic power of producers and workers, and hence the degree to which they restrict their respective supplies to raise prices and wages, thereby increasing the responsiveness of prices and wages to market conditions.

The next section presents the theoretical background to the model. Section 3 discusses the calibration and properties of the model. Section 4 assesses how changes in price and wage markups impact the world economy, and reports a simulation in which euro area markups fall to U.S. levels. Section 5 concludes. 


\section{The model}

\subsection{Consumption and investment goods}

The world economy consists of two countries, Home (the euro area) and Foreign (the rest of the industrial world). Foreign variables are indexed with a star. The structure of the model is illustrated in Figure $1 .{ }^{6}$

In each country there is a continuum of symmetric firms producing nontradable consumption $(A)$ and investment $(E)$ goods under perfect competition. Home firms producing the consumption good are indexed by $x \in[0, s]$ and Foreign firms are indexed by $x^{*} \in(s, 1]$, where $0<s<1$ is a measure of country size and world size is normalized to 1 .

Home firm $x$ 's output at time (quarter) $t$ is denoted $A_{t}(x) .{ }^{7}$ The consumption good is produced with the following CES technology:

$$
A_{t}(x)=\left(\nu_{A}^{\frac{1}{\mu_{A}}} Q_{A, t}(x)^{1-\frac{1}{\mu_{A}}}+\left(1-\nu_{A}\right)^{\frac{1}{\mu_{A}}}\left[M_{A, t}(x)\left(1-\Gamma_{M A, t}(x)\right)\right]^{1-\frac{1}{\mu_{A}}}\right)^{\frac{\mu_{A}}{\mu_{A}-1}}
$$

Two intermediate inputs are used in the production of the consumption good $A$ : a basket $Q_{A}$ of domestically-produced tradable goods, and a basket $M_{A}$ of imported tradable goods. The elasticity of substitution between domestic and imported inputs is $\mu_{A}>0$, while $\nu_{A} \in(0,1)$ is a measure of Home preferences toward domestic consumption goods.

To model sluggish adjustment of imports volumes to changes in demand, we assume that imports as a share of total production are subject to external adjustment $\operatorname{costs} \Gamma_{M A}:^{8}$

$$
\Gamma_{M A, t}(x) \equiv \frac{\phi_{M A}}{2}\left(\frac{M_{A, t}(x)}{A_{t}(x)} / \frac{M_{A, t-1}}{A_{t-1}}-1\right)^{2}
$$

As is the case for adjustment costs on investment dynamics, these adjustment costs temporarily shrink the production possibilities frontier of the economy.

\footnotetext{
${ }^{6}$ The model introduced in this section is a variant of the International Monetary Fund's Global Economy Model (GEM). For a detailed presentation of GEM see Laxton and Pesenti (2003) and Pesenti (2004).

${ }^{7}$ The convention throughout the model is that variables which are not explicitly indexed (to firms or households) are expressed in per-capita (average) terms. For instance, $A_{t} \equiv(1 / s) \int_{0}^{s} A_{t}(x) d x$.

${ }^{8}$ According to our specification, it is costly for the firm to adjust its current imports/output ratio $M_{A, t}(x) / A_{t}(x)$ relative to the past aggregate (sectoral) imports/output ratio $M_{A, t-1} / A_{t-1}$.
} 
The baskets $Q_{A}$ and $M_{A}$ are CES indexes of differentiated intermediate tradables, respectively produced in the Home country and imported from the Foreign country. Each intermediate good is produced by a single firm under conditions of monopolistic competition. Home firms in the tradables sector are indexed by $h \in[0, s]$, Foreign firms in the tradables sector are indexed by $f \in(s, 1]$. Defining as $Q_{A}(h, x)$ and $M_{A}(f, x)$ the use by firm $x$ of the intermediate goods produced by firms $h$ and $f$ respectively, we have:

$$
\begin{aligned}
& Q_{A, t}(x)=\left(\left(\frac{1}{s}\right)^{\frac{1}{\theta}} \int_{0}^{s} Q_{A, t}(h, x)^{1-\frac{1}{\theta}} d h\right)^{\frac{\theta}{\theta-1}} \\
& M_{A, t}(x)=\left(\left(\frac{1}{1-s}\right)^{\frac{1}{\theta^{*}}} \int_{s}^{1} M_{A, t}(f, x)^{1-\frac{1}{\theta^{*}}} d f\right)^{\frac{\theta^{*}}{\theta^{*}-1}}
\end{aligned}
$$

where $\theta, \theta^{*}>1$ are the elasticities of substitution across differentiated goods.

In the Home country, the prices of the intermediate goods are denoted $p(h)$ and $p(f)$. Each Home firm $x$ takes these prices as given and minimizes its costs. Home firm $x$ 's demand for input $h$ is then obtained as:

$$
Q_{A, t}(h, x)=\left(\frac{p_{t}(h)}{P_{Q, t}}\right)^{-\theta} \frac{Q_{A, t}(x)}{s}
$$

where $P_{Q}$ is the cost-minimizing price of one basket of local intermediates:

$$
P_{Q, t}=\left[\left(\frac{1}{s}\right) \int_{0}^{s} p_{t}(h)^{1-\theta} d h\right]^{\frac{1}{1-\theta}}
$$

Similarly we can derive $M_{A}(f, x)$ and $P_{M}$ - respectively firm $x$ 's optimal demand of imports $f$ and the cost-minimizing price of the import basket.

Next, each Home firm $x$ takes the prices of the intermediate baskets $P_{Q}$ and $P_{M}$ as given and minimizes $P_{Q, t} Q_{A, t}(x)+P_{M, t} M_{A, t}(x)$ subject to (1). Cost minimization in Home consumption good production yields:

$$
Q_{A, t}(x)=\nu_{A}\left(\frac{P_{Q, t}}{P_{t}}\right)^{-\mu_{A}} A_{t}(x), \quad M_{A, t}(x)=\left(1-\nu_{A}\right)\left(\frac{P_{M, t}}{P_{t} \Omega_{M A, t}(x)}\right)^{-\mu_{A}} \frac{A_{t}(x)}{1-\Gamma_{M A, t}(x)}
$$

where $P$ is the price of the consumption good and the variable $\Omega_{M A}(x)$ is a function of the 
imports/output ratio. ${ }^{9}$

Mutatis mutandis, the investment industry $E$ is similar to the consumption sector described above. Symmetric Home firms producing the investment good under perfect competition are indexed by $y \in[0, s]$, and Foreign firms by $y^{*} \in(s, 1]$. Home firm $y$ 's output is denoted $E_{t}(y)$. Using self-explanatory notation, output is given by:

$$
E_{t}(y)=\left(\nu_{E}^{\frac{1}{\mu_{E}}} Q_{E, t}(y)^{1-\frac{1}{\mu_{E}}}+\left(1-\nu_{E}\right)^{\frac{1}{\mu_{E}}}\left[M_{E, t}(y)\left(1-\Gamma_{M E, t}(y)\right)\right]^{1-\frac{1}{\mu_{E}}}\right)^{\frac{\mu_{E}}{\mu_{E}-1}}
$$

and the other variables related to $E$ can be similarly derived. ${ }^{10}$

Aggregating across $x$ - and $y$-type firms we obtain the following Home demand for intermediate domestic good $h$ :

$$
\int_{0}^{s} Q_{A, t}(h, x) d x+\int_{0}^{s} Q_{E, t}(h, y) d y=\left(\frac{p_{t}(h)}{P_{Q, t}}\right)^{-\theta}\left(Q_{A, t}+Q_{E, t}\right)
$$

Similar considerations apply to Home demand for intermediate imported good $f$, accounting for differences in country size:

$$
\int_{0}^{s} M_{A, t}(f, x) d x+\int_{0}^{s} M_{E, t}(f, y) d y=\frac{s}{1-s}\left(\frac{p_{t}(f)}{P_{M, t}}\right)^{-\theta^{*}}\left(M_{A, t}+M_{E, t}\right)
$$

Foreign variables are similarly characterized.

\subsection{Intermediate goods}

The supply of each Home intermediate good $h$ is denoted by $T(h)$ :

$$
T_{t}(h)=Z_{t}\left\{(1-\alpha)^{\frac{1}{\xi}} \ell_{t}(h)^{1-\frac{1}{\xi}}+\alpha^{\frac{1}{\xi}} K_{t}(h)^{1-\frac{1}{\xi}}\right\}^{\frac{\xi}{\xi-1}}
$$

Firm $h$ uses labor $\ell(h)$ and capital $K(h)$ with constant elasticity of input substitution $\xi>0$ and capital weight $0<\alpha<1$, while $Z$ is a scale parameter (total factor productivity).

${ }^{9}$ To wit, $\Omega_{M A, t}(x) \equiv 1-\Gamma_{M A, t}(x)-\phi_{M A}\left(\frac{M_{t}(x)}{A_{t}(x)} / \frac{M_{t-1}}{A_{t-1}}-1\right)\left(\frac{M_{t}(x)}{A_{t}(x)} / \frac{M_{t-1}}{A_{t-1}}\right)$.

${ }^{10}$ For instance, Home firm $y$ 's demand for the basket of local intermediates is:

$$
Q_{E, t}(y)=\left[\left(\frac{1}{s}\right)^{\frac{1}{\theta}} \int_{0}^{s} Q_{E, t}(h, y)^{1-\frac{1}{\theta}} d h\right]^{\frac{\theta}{\theta-1}}=\nu_{E}\left(\frac{P_{Q, t}}{P_{E, t}}\right)^{-\mu_{E}} E_{t}(y)
$$

where $P_{E}$ is the price of one unit of $E$. 
Each firm $h$ uses a CES combination of differentiated labor inputs. Labor inputs are immobile geographically. In each country, they are defined over a continuum of mass equal to the country size: Home labor inputs are indexed by $j \in[0, s]$, Foreign labor inputs by $j^{*} \in(s, 1]$. We can then write:

$$
\ell_{t}(h)=\left[\left(\frac{1}{s}\right)^{\frac{1}{\psi}} \int_{0}^{s} \ell(h, j)^{1-\frac{1}{\psi}} d j\right]^{\frac{\psi}{\psi-1}}
$$

where $\ell(h, j)$ is the demand of the labor input of type $j$ by the producer of good $h$ and $\psi>1$ is the elasticity of substitution among labor inputs.

Firms producing intermediate goods take the prices of labor inputs and capital as given. Cost minimization in the intermediate sector implies that the demand for labor input $j$ by firm $h$ is a function of the relative wage:

$$
\ell_{t}(h, j)=\left(\frac{1}{s}\right)\left(\frac{W_{t}(j)}{W_{t}}\right)^{-\psi} \ell_{t}(h)
$$

where $W(j)$ is the nominal wage paid to Home labor input $j$ and the wage index $W$ is defined as:

$$
W_{t}=\left[\left(\frac{1}{s}\right) \int_{0}^{s} W_{t}(j)^{1-\psi} d j\right]^{\frac{1}{1-\psi}}
$$

Denoting by $R$ the Home nominal rental price of capital, cost minimization yields:

$$
\ell_{t}(h)=(1-\alpha)\left(\frac{W_{t}}{M C_{t}(h)}\right)^{-\xi} \frac{T_{t}(h)}{Z_{t}}, \quad K_{t}(h)=\alpha\left(\frac{R_{t}}{M C_{t}(h)}\right)^{-\xi} \frac{T_{t}(h)}{Z_{t}}
$$

where the marginal cost $M C(h)$ is given by:

$$
M C_{t}(h)=\left((1-\alpha) W_{t}^{1-\xi}+\alpha R_{t}^{1-\xi}\right)^{\frac{1}{1-\xi}} / Z_{t}
$$

Similar considerations hold for the production of Foreign intermediates.

\subsection{Price setting in the intermediate sector}

Consider now profit maximization in the Home country's intermediate sector. In both markets there is sluggish price adjustment due to resource costs measured in terms of total 
profits. ${ }^{11}$ The adjustment cost are denoted $\Gamma_{P Q, t}(h)$ and $\Gamma_{P M, t}^{*}(h)$ :

$$
\Gamma_{P Q, t}(h) \equiv \frac{\phi_{Q}}{2}\left(\frac{p_{t}(h) / p_{t-1}(h)}{P_{Q, t-1} / P_{Q, t-2}}-1\right)^{2}, \quad \Gamma_{P M, t}^{*}(h) \equiv \frac{\phi_{M}^{*}}{2}\left(\frac{p_{t}^{*}(h) / p_{t-1}^{*}(h)}{P_{M, t-1}^{*} / P_{M, t-2}^{*}}-1\right)^{2}
$$

where $\phi_{Q}, \phi_{M}^{*}, \geq 0$. The quadratic costs of price adjustment are related to changes in firm $h$ 's price inflation relative to the past observed inflation rate in the relevant market, allowing the model to reproduce realistic inflation dynamics encompassing nominal inertias. Each firm $h$ takes into account the demand for its product in both countries (that is, expression (9) and the Foreign-country analog of expression (10)) and sets the nominal prices $p(h)$ in the Home market and $p^{*}(h)$ in the Foreign market by maximizing the present discounted value of its real profits.

Formally, denoting the nominal exchange rate as $\mathcal{E}$ (defined as Home currency per unit of Foreign currency), firm $h$ sets its prices by maximizing its profits:

$$
\begin{aligned}
& \max _{\left\{p_{\tau}(h), p_{\tau}^{*}(h)\right\}_{\tau=t}^{\infty}} \mathrm{E}_{t} \sum_{\tau=t}^{\infty} D_{t, \tau}\left[\left(p_{\tau}(h)-M C_{\tau}(h)\right)\left(\frac{p_{\tau}(h)}{P_{Q, \tau}}\right)^{-\theta}\left(Q_{A, \tau}+Q_{E, \tau}\right)\left(1-\Gamma_{P Q, \tau}(h)\right)\right. \\
& \left.+\left(\mathcal{E}_{\tau} p_{\tau}^{*}(h)-M C_{\tau}(h)\right)\left(\frac{p_{\tau}^{*}(h)}{P_{M, \tau}^{*}}\right)^{-\theta}\left(M_{A, \tau}^{*}+M_{E, \tau}^{*}\right)\left(\frac{1-s}{s}\right)\left(1-\Gamma_{P M, \tau}^{*}(h)\right)\right]
\end{aligned}
$$

where $D_{t, \tau}$ is the appropriate discount rate (with $D_{t, t}=1$ ), to be defined below.

Denoting $\pi_{t}(h)=p_{t}(h) / p_{t-1}(h)$ and $\pi_{Q, t}=P_{Q, t} / P_{Q, t-1}$, the first-order condition with respect to $p_{t}(h)$ can be written as:

$$
\begin{aligned}
& \left(1-\Gamma_{P Q, t}(h)\right)\left(p_{t}(h)(1-\theta)+\theta M C_{t}(h)\right)-\left(p_{t}(h)-M C_{t}(h)\right) \frac{\partial \Gamma_{P Q, t}(h)}{\partial p_{t}(h)} p_{t}(h) \\
& =\mathrm{E}_{t}\left(D_{t, t+1}\left(p_{t+1}(h)-M C_{t+1}(h)\right)\left(\frac{Q_{A, t+1}+Q_{E, t+1}}{Q_{A, t}+Q_{E, t}}\right)\left(\frac{\pi_{t+1}(h)}{\pi_{Q, t+1}}\right)^{-\theta} \frac{\partial \Gamma_{P Q, t+1}(h)}{\partial p_{t}(h)} p_{t}(h)\right)
\end{aligned}
$$

Equation (19) is key to our results. First, note that when prices are fully flexible $\left(\phi_{Q}=\right.$ 0 ), the optimization problem collapses to the standard markup rule:

$$
p_{t}(h)=\frac{\theta}{\theta-1} M C_{t}(h)
$$

\footnotetext{
${ }^{11}$ See among others Rotemberg (1982) and Ireland (2001).
} 
where the fixed gross markup $\theta /(\theta-1)$ is a negative function of the elasticity of input substitution. When $\phi_{Q}>0$, changes in marginal costs translate only gradually into changes in prices as instantaneous adjustment is costly (left hand side), but not too gradually to avoid excessive adjustment in the future (right hand side).

More crucially, (19) clarifies the link between imperfect competition and nominal rigidities. When $\theta$ is very large, $(19)$ is solved by $p_{t}(h) \approx M C_{t}(h)$ regardless of how sizable $\phi_{Q}$ is. This implies that in a competitive economy (large $\theta$ ) prices must move in tandem with the shocks affecting marginal costs, even though such flexibility entails large adjustment costs. Instead, if price setters have strong monopoly power ( $\theta$ is close to one, its minimum value), they can charge a high average markup over marginal costs. In this case, when marginal costs increase due to cyclical conditions, firms find it optimal to maintain relatively stable prices and absorb the change in production costs through a markup squeeze. In other words, when $\theta$ is small, firms are able to keep their prices well above marginal costs and accommodate changes in demand through supply adjustments, without corresponding changes in prices. Other things being equal, an increase in $\theta$ reduces the firms' ability to use markup fluctuations as a shock absorber.

Similar considerations hold for the price of good $h$ abroad, $p^{*}(h)$. If nominal rigidities in the export market are highly relevant (that is, if $\phi_{M}^{*}$ is relatively large), the prices of Home goods in the Foreign market will be characterized by significant inertia. ${ }^{12}$ In the absence of price stickiness, instead, optimal price setting is consistent with the cross-border law of one price:

$$
\mathcal{E}_{t} p_{t}^{*}(h)=\frac{\theta}{\theta-1} M C_{t}(h)
$$

Foreign variables are similarly characterized.

\footnotetext{
${ }^{12}$ Substantially, this is the 'local currency pricing' scenario with low exchange rate pass-through analyzed by Devereux and Engel (2003), Corsetti and Pesenti (2001) and others.
} 


\subsection{Consumer optimization}

In each country there is a continuum of symmetric households. Home households are indexed by $j \in[0, s]$ and Foreign households by $j^{*} \in(s, 1]$, the same indexes of labor inputs. Households' preferences are additively separable in consumption and labor effort. Denoting with $\mathcal{W}_{t}(j)$ the lifetime expected utility of Home agent $j$, we have:

$$
\mathcal{W}_{t}(j) \equiv \mathrm{E}_{t} \sum_{\tau=t}^{\infty} \beta^{\tau-t}\left[U_{\tau}\left(C_{\tau}(j)\right)-V_{\tau}\left(\ell_{\tau}(j)\right)\right]
$$

where $\beta$ is the discount rate, assumed to be identical across countries.

There is habit persistence in consumption according to the specification:

$$
U_{t}^{\prime}(j)=\left(\frac{C_{t}(j)-b_{C} C_{t-1}}{1-b_{C}}\right)^{-\sigma}
$$

where $U^{\prime}(j)$ is the marginal utility, $C_{t-1}$ is past per-capita Home consumption and $0 \leq$ $b_{C}<1$. Similarly, the parametric specification of $V$ is such that:

$$
V_{t}^{\prime}(j)=\left(\frac{\ell_{t}(j)-b_{\ell} \ell_{t-1}}{1-b_{\ell}}\right)^{\zeta}
$$

where $V^{\prime}(j)$ is the marginal disutility of labor effort, $\zeta$ is the inverse of the Frisch elasticity of labor supply and $0 \leq b_{\ell}<1 .{ }^{13}$ Foreign agent $j^{*}$ s preferences are similarly specified.

The individual flow budget constraint for agent $j$ in the Home country is:

$$
\begin{aligned}
& \mathcal{M}_{t}(j)+\mathcal{E}_{t} B_{t}^{*}(j)+B_{t}(j) \leq W_{t}(j) \ell_{t}(j)\left[1-\Gamma_{W, t}(j)\right]-P_{t} C_{t}(j)\left[1+\Gamma_{S, t}(j)\right]-P_{E, t} I_{t}(j)+\Phi_{t} \\
& -T T_{t}(j)+R_{t} K_{t}(j)+\mathcal{M}_{t-1}(j)+\left(1+i_{t-1}^{*}\right)\left[1-\Gamma_{B, t-1}\right] \mathcal{E}_{t} B_{t-1}^{*}(j)+\left(1+i_{t-1}\right) B_{t-1}(j)
\end{aligned}
$$

Home agents hold domestic money $\mathcal{M}$ and two bonds, $B$ and $B^{*}$, denominated in Home and Foreign currency, respectively. The short-term nominal rates $i_{t-1}$ and $i_{t-1}^{*}$ are paid at the beginning of period $t$ and are known at time $t-1 .^{14}$ The two short-term rates

\footnotetext{
${ }^{13}$ This specification allows for habit persistence in labor effort and is not standard in the literature. It allows for the possibility that there can be additional costs to large business cycles if they result in excessive variability in labor effort.

${ }^{14}$ Our timing convention has $B_{t-1}(j)$ and $B_{t-1}^{*}(j)$ as agent $j$ 's nominal bonds accumulated during period $t-1$ and carried over into period $t$.
} 
are directly controlled by the national governments. Without loss of generality, only one bond (namely, the Foreign-currency one) is traded internationally and is in zero net supply worldwide, while the other (Home) bond is in zero net supply at the domestic level. ${ }^{15} \mathrm{~A}$ financial friction $\left(\Gamma_{B}\right)$ is introduced to guarantee that net asset positions follow a stationary process and the economies converge asymptotically to a steady state, that is the baseline in our simulation exercises. ${ }^{16}$

Home agents accumulate Home physical capital which they rent to Home firms at the nominal rate $R$. The law of motion of capital is:

$$
K_{t+1}(j)=(1-\delta) K_{t}(j)+\Psi_{t} K_{t}(j) \quad 0<\delta \leq 1
$$

where $\delta$ is the depreciation rate. To simulate realistic investment flows, capital accumulation is subject to adjustment costs. Capital accumulation is denoted $\Psi_{t} K_{t}(j)$, where $\Psi($.$) is a$ function of the investment/capital ratio $I_{t}(j) / K_{t}(j)$ such that $\Psi(\delta)=\delta$ and $\Psi^{\prime}(\delta)=1$. The specific functional form we adopt is quadratic and encompasses inertias in investment:

$$
\Psi_{t} \equiv \frac{I_{t}(j)}{K_{t}(j)}-\frac{\phi_{I 1}}{2}\left(\frac{I_{t}(j)}{K_{t}(j)}-\delta\right)^{2}-\frac{\phi_{I 2}}{2}\left(\frac{I_{t}(j)}{K_{t}(j)}-\frac{I_{t-1}}{K_{t-1}}\right)^{2}
$$

where $\phi_{I 1}, \phi_{I 2} \geq 0$.

Each household is the monopolistic supplier of a labor input $j$. Each household sets the nominal wage for type $j$-labor input facing a downward-sloping demand, obtained by aggregating (13) across $h$-firms. As in Kim (2000), there is sluggish wage adjustment due to resource costs that are measured in terms of the total wage bill. The adjustment cost is denoted $\Gamma_{W, t}$, with:

$$
\Gamma_{W, t}(j) \equiv \frac{\phi_{W}}{2}\left(\frac{W_{t}(j) / W_{t-1}(j)}{W_{t-1} / W_{t-2}}-1\right)^{2}
$$

\footnotetext{
${ }^{15}$ International arbitrage makes the second bond redundant for consumption-smoothing purposes.

${ }^{16}$ Home agents face a transaction $\operatorname{cost} \Gamma_{B}$ when they take a position in the Foreign bond market. This cost depends on the average net asset position of the whole economy, that is $(1 / s) \mathcal{E} \int_{0}^{s} B^{*}(j) d j / P$, and is zero only when Home agents do not hold any Foreign-currency assets $\left(\Gamma_{B}(0)=0\right)$. This implies that in a non-stochastic steady state Home agents have no incentive to hold Foreign bonds and net asset positions are zero worldwide.
} 
where $\phi_{W} \geq 0$. As was the case for prices above, wage adjustment costs are related to changes in wage inflation relative to the past observed rate for the whole economy.

Consumption spending is subject to a proportional transaction cost $\Gamma_{S}$ that depends on the household's money velocity $v_{t}(j) \equiv P_{t} C_{t}(j) / \mathcal{M}_{t}(j)$. Agents optimally choose their stock of real money holdings $\mathcal{M} / P$ so that at the margin shopping costs measured in terms of foregone consumption are equal to the benefits from investing in yield-bearing assets. ${ }^{17}$

Home agents own all Home firms and there is no international trade in claims on firms' profits. The variable $\Phi$ includes all profits accruing to Home households, plus all Homecurrency revenue from nominal adjustment rebated in a lump-sum way to all Home households, plus revenue from financial intermediation which is assumed to be provided by Home firms exclusively. Finally, Home agents pay lump-sum (non-distortionary) net taxes $T T_{t}(j)$ denominated in Home currency. Similar relations hold in the Foreign country, with the exception of the intermediation frictions in the financial market.

The representative Home household chooses bond and money holdings, capital and consumption paths, and sets wages to maximize its expected lifetime utility (22) subject to (25) and (26). Defining the variable $D_{t, \tau}$ as:

$$
D_{t, \tau} \equiv \beta \frac{P_{t} U^{\prime}\left(C_{\tau}\right)\left[1+\Gamma_{S, t}+\Gamma_{S, t}^{\prime} v_{t}\right]}{P_{\tau} U^{\prime}\left(C_{t}\right)\left[1+\Gamma_{S, \tau}+\Gamma_{S, \tau}^{\prime} v_{\tau}\right]}
$$

which is Home agents' stochastic discount rate and the Home pricing kernel, the first-order conditions with respect to $B_{t}(j)$ and $B_{t}^{*}(j)$ are, respectively:

$$
1=\left(1+i_{t}\right) \mathrm{E}_{t} D_{t, t+1}=\left(1+i_{t}^{*}\right)\left(1-\Gamma_{B, t}\right) \mathrm{E}_{t}\left(D_{t, t+1} \mathcal{E}_{t+1} / \mathcal{E}_{t}\right)
$$

The above expression is the risk-adjusted uncovered-interest-parity relationship, recalling that the return on lending to Foreign is reduced (and the cost of borrowing from Foreign is increased) by the costs of intermediation $\Gamma_{B}$. The first-order conditions with respect to $\mathcal{M}_{t}(j)$ and $K_{t+1}(j)$ are standard. Real money balances $\mathcal{M} / P$ are a positive function of

\footnotetext{
${ }^{17}$ Following Schmitt-Grohe and Uribe (2004), the particular functional form for the transaction cost is $\Gamma_{S}\left(v_{t}\right)=\phi_{S 1} v_{t}+\phi_{S 2} / v_{t}-2 \sqrt{\phi_{S 1} \phi_{S 2}}$.
} 
consumption and a negative function of the nominal interest rate. In steady state the real price of capital $1+R / P_{E}$ is equal to the sum of the rate of time preference $1 / \beta$ and the rate of capital depreciation $\delta$.

More relevant for our purposes is the first order condition with respect to $W_{t}(j)$, whose dynamics is the analog of the price equation (19) above. In the absence of wage rigidities $\left(\phi_{W}=0\right)$ the real wage $W_{t}(j) / P_{t}$ is equal to the marginal rate of substitution between consumption and leisure, $V_{t}^{\prime} / U_{t}^{\prime}$, augmented by the markup $\psi /(\psi-1)$ which reflects monopoly power in the labor market.

Optimization implies that households exhaust their intertemporal budget constraint: the flow budget constraint (25) holds as equality and the transversality condition is satisfied:

$$
\lim _{\tau \rightarrow \infty} \mathrm{E}_{t} D_{t, \tau}\left[\mathcal{M}_{\tau-1}(j)+\left(1+i_{\tau}\right) B_{\tau-1}(j)+\left(1+i_{\tau}^{*}\right)\left(1-\Gamma_{B, \tau-1}\right) \mathcal{E}_{\tau} B_{\tau-1}^{*}(j)\right]=0
$$

Similar results characterize the optimization problem of Foreign agent $j^{*}$.

\subsection{Government}

Public spending falls both on consumption and investment goods. In the model $G_{C}$ is per-capita public purchases of the Home consumption goods and $G_{I}$ is public investment, financed through net lump-sum taxes and seigniorage revenue. The budget constraint of the Home government is:

$$
s P_{t} G_{C, t}+s P_{E, t} G_{I, t} \leq \int_{0}^{s} T T_{t}(j) d j+\int_{0}^{s}\left[\mathcal{M}_{t}(j)-\mathcal{M}_{t-1}(j)\right] d j
$$

The government controls the short-term rate $i_{t}$. Monetary policy is specified in terms of an annualized Taylor rule ${ }^{18}$ of the form:

$$
\begin{aligned}
& \left(1+i_{t}\right)^{4}-1=\omega_{i}\left[\left(1+i_{t-1}\right)^{4}-1\right] \\
& +\left(1-\omega_{i}\right)\left[\left(1+\overline{i_{t}}\right)^{4}-1\right]+\omega_{1}\left[\frac{P_{t}}{P_{t-4}}-\Pi_{t}\right]+\omega_{2} Y G A P_{t}
\end{aligned}
$$

\footnotetext{
${ }^{18}$ See Taylor (1993).
} 
where the left hand side is the annualized interest rate, $i_{t}$ is the lagged interest rate (with $\left.0<\omega_{i}<1\right)$ and $\overline{i_{t}}$ is the natural interest rate, defined as:

$$
\left(1+\overline{i_{t}}\right)^{4}=\frac{1}{\beta^{4}} \frac{P_{t}}{P_{t-4}}
$$

In the expression above $P_{t} / P_{t-4}$ is the year-on-year gross CPI inflation rate, and $\Pi_{t}$ is the year-on-year gross inflation target. ${ }^{19}$ The term $Y G A P$ denotes the output gap, which will be defined in equation (40) below.

Foreign variables are similarly characterized. Any steady-state discrepancy between $i$ and $i^{*}$ (thus, between $\Pi$ and $\Pi^{*}$ ) determines the steady-state rate of exchange rate depreciation (for $\Pi>\Pi^{*}$ ) or appreciation (for $\Pi<\Pi^{*}$ ).

\subsection{Market clearing}

The model is closed by imposing the following resource constraints and market clearing conditions. The Home tradable $h$ can be used by Home firms or imported by Foreign firms, so that:

$$
T(h) \geq \int_{0}^{s} Q_{A, t}(h, x) d x+\int_{0}^{s} Q_{E, t}(h, y) d y+\int_{s}^{1} M_{A, t}^{*}\left(h, x^{*}\right) d x^{*}+\int_{s}^{1} M_{E, t}^{*}\left(h, y^{*}\right) d y^{*}
$$

The Home good $A$ can be used for private or public consumption, and similarly the Home good $E$ is used for private or public investment:

$$
\begin{aligned}
\int_{0}^{s} A_{t}(x) d x & \geq \int_{0}^{s} C_{t}(j)\left[1+\Gamma_{S, t}(j)\right] d j+s G_{C, t} \\
\int_{0}^{s} E_{t}(y) d y & \geq \int_{0}^{s} I_{t}(j) d j+s G_{I, t}
\end{aligned}
$$

The resource constraints for labor and capital are:

$$
\ell_{t}(j) \geq \int_{0}^{s} \ell_{t}(h, j) d h \quad \int_{0}^{s} K_{t}(j) d j \geq \int_{0}^{s} K_{t}(h) d h
$$

\footnotetext{
${ }^{19}$ In a steady state with constant inflation target $\Pi$ it is: $\pi=P_{t} / P_{t-1}=\left(P_{t} / P_{t-4}\right)^{0.25}=\Pi^{0.25}$, and when all targets are reached it must be the case that: $1+i_{t}=1+\overline{i_{t}}=\Pi^{0.25} / \beta$.
} 
Similar expressions hold abroad. ${ }^{20}$

Finally, market clearing in the asset market requires:

$$
\int_{0}^{s} B_{t}(j) d j=0, \quad \int_{0}^{s} B_{t}^{*}(j) d j+\int_{s}^{1} B_{t}^{*}\left(j^{*}\right) d j^{*}=0
$$

Aggregating the budget constraints across private and public agents we derive the macroeconomic variables used in the simulation exercises. In particular, the output gap that enters the policy rule (33) is defined as the deviation of real (constant-price) national income from baseline:

$$
\begin{aligned}
& Y G A P_{t} \equiv A_{t}+\frac{P_{E}}{P} E_{t}+\frac{P_{M}^{*} \mathcal{E}}{P}\left(\frac{1-s}{s}\right)\left(M_{A, t}^{*}+M_{E, t}^{*}\right)-\frac{P_{M}}{P}\left(M_{A, t}+M_{E, t}\right) \\
& -\left(A+\frac{P_{E}}{P} E+\frac{P_{M}^{*} \mathcal{E}}{P}\left(\frac{1-s}{s}\right)\left(M_{A}^{*}+M_{E}^{*}\right)-\frac{P_{M}}{P}\left(M_{A}+M_{E}\right)\right)
\end{aligned}
$$

where variables without time index denote steady-state levels. ${ }^{21}$

\section{Calibration and model properties}

In our simulations the Home country (euro area) is assumed to make up 35 percent of the industrial world, and the Foreign country is the rest of the industrial world with $1-s=$ $0.65 .^{22}$ Table 1 provides a summary of the main parameter values as well as steady-state levels in the baseline solution of the model. In addition, Table 4 reports the elasticities of substitution among labor inputs $(\psi)$ and among differentiated goods $(\theta)$, as well as the underlying steady-state wage and price markups, $\psi /(\psi-1)$ and $\theta /(\theta-1)$. In what follows we discuss our assumptions.

\footnotetext{
${ }^{20}$ It is worth noticing that in equilibrium $p(n)=P_{N}, p(h)=P_{Q}, p(f)=P_{M}, p^{*}(n)=P_{N}^{*}, p^{*}(h)=P_{M}^{*}$, $p^{*}(f)=P_{Q}^{*}, W(j)=W, W^{*}\left(j^{*}\right)=W^{*}$.

${ }^{21}$ In the model, real income and other macro variables are measured in terms of consumption baskets, and thereby affected by current changes in relative prices. In the simulation exercises where we compare our results to other models, which are based on data from national accounts, our measure of real (constant-dollar) GDP is obtained by evaluating expenditures using fixed (steady-state) relative prices.

${ }^{22}$ To calibrate the dynamics of the Foreign country we rely heavily upon model results for the U.S. economy.
} 


\subsection{Assumptions about elasticities}

The inverse of the parameter $\zeta$ represents the Frisch elasticity of labor supply, which in the baseline calibration of the model has been set to $1 / 3(\zeta=3)$. This estimate is at the high end of the range of estimates from micro studies, which vary from about .05 to .35 , but is significantly lower than what is typically used in the real business cycle literature (see e.g. Cooley and Prescott (1995)). Because the results are sensitive to the assumption about this parameter value, an alternative estimate that is closer to the mean estimates from micro studies $(0.15$ or $\zeta=6.7)$ is also considered. ${ }^{23}$

In the baseline calibration of the model we set the elasticity of substitution between domestic and imported inputs in the production of consumption and investment goods $\left(\mu_{A}\right.$ and $\mu_{E}$ ) equal to 2.5. These elasticities are critical determinants of the long-run spillover effects of changes in the degree of competition in one country on other countries, because they affect the behavior of net exports and the real exchange rate. An estimate of 2.5 is lower than the estimate employed by Erceg, Guerrieri and Gust (2003) in a model of the US economy, ${ }^{24}$ but it is significantly higher than what has been used in several previous macro simulation models (e.g., see Laxton and others (1998), Chari, Kehoe and McGrattan (2002), Smets and Wouters (2002a), and Gali and Monacelli (2002)). The section on sensitivity analysis shows the implications of reducing $\mu_{A}$ and $\mu_{E}$ to 1.5 .

\subsection{Assumptions about steady-state ratios}

The following steady-state ratios are calibrated to be consistent with national accounts data. The steady-state investment-to-GDP ratio is 22 percent in both countries, with 19 percent representing private sector investment and 3 percent investment by the government. Based

\footnotetext{
${ }^{23}$ See the discussion in Galí, Gertler, and López-Salido (2002).

${ }^{24}$ The authors argue that, in models with significant adjustment costs on imports, a large long-run import price elasticity is not inconsistent with smaller estimates of short-run and medium-term elasticities as derived from aggregate trade equations.
} 
on a quarterly depreciation rate of 2.5 percent and identical total factor productivity in the two countries $\left(Z=Z^{*}\right)$, this implies a steady-state capital-to-GDP ratio of around 2.2. The values for $\alpha$ and $\alpha^{*}$, the weight of capital in the production of tradables, imply a smaller labor income share in the Home country (47 percent) than in the Foreign country (58 percent), consistent with OECD data.

The import-to-GDP ratio is set at 18 percent for the euro area and 13 percent for the rest of the world (which is approximately the openness of the U.S. economy). Approximately two thirds of imported goods in the euro area are investment goods, while for the United States this figure is only slightly greater than one half. Consistently, the steady-state level of imports of investment goods relative to GDP is 13 percent in the euro area and 7 percent in the rest of the industrial world, allocating the remainder to imports of consumption goods. These ratios were calibrated by setting the appropriate values for the scale parameters $\left(\nu_{A}\right.$ and $\left.\nu_{E}\right)$ in the import demand functions for both the Home and Foreign economies.

\subsection{Assumptions about dynamics}

As regards the short-term dynamic properties of the model, the appropriate parameters have been calibrated to approximately replicate the monetary transmission mechanisms embedded in policy simulation models developed at the European Central Bank (ECB) and the Federal Reserve Board of Governors (FRB). ${ }^{25}$ The empirical apparatus of these models does not build upon a choice-theoretic structure, but rather reflects the results of vector autoregression (VAR) analysis as well as information specific to the two institutions. In particular, our calibration mimics the dynamic responses to a 1-year interest rate hike in the ECB's Area-Wide Model (AWM) and the Board of Governor's FRB-US model, followed

\footnotetext{
${ }^{25}$ Our calibration gives rise to a plausible, empirically-based, representation of macroeconomic dynamics. At a minimum, it establishes a sensible set of initial priors based on central bank modelers' views about the monetary transmission mechanism, setting the stage for the introduction of Bayesian estimation methods as considered in Sims (2002).
} 
by reversal to the baseline Taylor rule (33). ${ }^{26}$

Table 2 reports the responses of key macro-variables to a 1-year hike in the policy rate in the Home country of our model, and compares these responses with results from the same experiment using the ECB's AWM. ${ }^{27}$ Table 3 repeats the same experiment for the Foreign economy, and the results are compared with those of the FRB-US model. ${ }^{28}$ To make the results more easily comparable we have included a summary column in Table 2 and 3 that reports the sum of the responses over the first two years of the simulation horizon.

In both the AWM and FRB-US model, the maximum effect on consumption occurs after about 3-4 quarters and the peak is about 3 to 4 times larger than the impact effect in the first quarter. To obtain a similar hump-shaped response of consumption in our simulations we combine a fairly high value for the consumption habit persistence parameter ( $b_{C}=0.97$ in both countries) with relatively high values for the intertemporal elasticity of substitution $(1 / \sigma)$. In fact, in the simulations reported in Tables 2 and 3 we set $1 / \sigma$ equal to 5.0 in both countries. While the values of these elasticities are above the point estimates typically adopted in structural models that ignore or downplay habit persistence, in the context of our model they generate a realistically gradual build-up of the effects of interest rate hikes over time, even in the absence of artificial assumptions such as predetermined consumption expenditures and decision lags. An alternative parameterization based on a more conventional logarithmic utility is discussed below. ${ }^{29}$

To better assess the interaction of habit persistence and intertemporal substitution in generating delayed consumption responses, Figure 2 reports some sensitivity analysis for

\footnotetext{
${ }^{26}$ The rule in the simulations places equal weights of 0.5 on the output gap $\left(\omega_{2}\right)$, the inflation gap $\left(\omega_{1}\right)$, and the interest rate smoothing term $\left(\omega_{i}\right)$. The money demand parameters $\phi_{S 1}$ and $\phi_{S 2}$ are set at 0.011 and 0.075 respectively as in Laxton and Pesenti (2003).

${ }^{27}$ These responses are reported in Fagan, Henry and Mestre (2001).

${ }^{28}$ The FRB-US results were kindly provided by David Reifschneider.

${ }^{29}$ When preferences are additive over consumption and leisure, the main virtue of logarithmic utility is that it gives rise to a balanced growth path.
} 
exactly the same experiments conducted in Table 2 and 3 . The top panel reports consumption responses for the Home country without habit persistence in consumption $\left(b_{C}=0\right)$ for three values of the intertemporal elasticity of substitution that range between $1 / 3$ and 3.0 , with an intermediate case of 0.99 that approximates the assumption of logarithmic utility. The top panel shows that without habit persistence, consumption behaves as a pure jump variable in response to interest rate hikes, and indeed in all three cases consumption peaks (unrealistically) in the very first period when the shock is assumed to take place. The two middle panels report results when the habit persistence parameter as been set at 0.6 and 0.8 respectively, well within the consensus range of estimates for $b$. Consumption in these simulations falls significantly in the period when the shock occurs, and its magnitude grows only slightly over the next two quarters before quickly reverting to baseline. Realistic dynamics is obtained only with a combination of high habit persistence and low values of $\sigma$, as assumed in our calibration. ${ }^{30}$ Despite the close similarity of the dynamic paths, however, it is worth noticing that in both the AWM and FRB-US model consumption reverts to baseline more slowly than in the simulated responses of our model.

To illustrate the implications of habit persistence in labor effort, Figure 3 shows the responses of some key macrovariables to a permanent decline in the inflation target of the Home country under different assumptions on the value of $b_{\ell}$. As can be seen in the Figure, high values of this parameter induce high persistence in the economy, as it can take well over a decade for the economy to return to equilibrium following a disinflationary episode. Based on our preliminary econometric analysis of U.S. data, we set $b_{\ell}$ equal to 0.5 in both countries. ${ }^{31}$

\footnotetext{
${ }^{30}$ To understand how combinations of $b_{C}$ and $\sigma$ generate different dynamic responses it may be useful to consider the linearized version of the Euler equation (30), ignoring transaction costs $\Gamma_{S}$ in eq. (29): $c_{t}=\frac{b_{C}}{1+b_{C}} c_{t-1}+\mathrm{E}_{t} \frac{1}{1+b_{C}} c_{t+1}-\frac{i_{t}-\mathrm{E}_{t} p_{t+1}+p_{t}}{\sigma\left(1+b_{C}\right)}$. As can be seen from this equation a habit persistence parameter that approaches 1 induces a first-order lag that approaches $1 / 2$ and, for a given $\sigma$, reduces the sensitivity of consumption to changes in the real interest rate.

${ }^{31} \mathrm{~A}$ caveat is worth mentioning. Our initial empirical work was based on pre-filtering the data prior to estimation. We expect that estimates of parameters such as $b_{\ell}$, which fundamentally influence the speed of
} 
A number of parameters have been calibrated to generate investment responses as consistent as possible with the central bank models mentioned above. The elasticity of substitution between capital and labor in the production function $(\xi)$ is set at 0.80 in the Home country and 0.70 in the Foreign country. ${ }^{32}$ Our model calibration assigns significant adjustment costs to changes in investment ( $\phi_{I 2}=70$ for the Home country and 80 for the Foreign country) and very small adjustment costs to capital accumulation $\left(\phi_{I 1}=1\right.$ for both countries). ${ }^{33}$ While these assumptions help to attenuate the volatility of investment in our simulations, we note however that the estimated short-run responses may still be too sensitive to interest rate shocks.

Likewise, import adjustment costs have been calibrated to slow down the responsiveness of the import shares to changes in relative prices. In our simulations it takes several quarters before the import share adjusts to a permanent real depreciation. Over a time horizon of about two years, the effective elasticity of the import share with respect to the real exchange rate is around 1.5 .

The remaining dynamic coefficients to be calibrated are the adjustment cost parameters on wages, prices and import prices. Given the empirical paucity of reliable estimates, it was decided to allow for a baseline calibration based on full pass-through onto import prices $\left(\phi_{M}=0\right)$ and identical adjustment costs on wages and domestic prices. ${ }^{34} \mathrm{~A}$ value of 2800 for $\phi_{W}$ and $\phi_{Q}$ is capable of approximately replicating the slow response of the price level in the ECB's model of the euro area and a value of 1400 is capable of replicating the significantly faster response of the price level in the FRB-US model. Based on these parameters, the adjustment of the model, might well contain significant pre-filter bias.

${ }^{32}$ The parameters are different as the sensitivity of investment to interest rates appears to vary between the euro area and the United States.

${ }^{33}$ This calibration of the adjustment costs for investment dynamics is very similar to Altig and others (2003) who assume zero adjustment costs on capital formation but significant adjustment costs on the change in investment.

${ }^{34}$ Sensitivity analysis shows that our results do not change significantly when we relax these assumptions. 
sacrifice ratios are equal to 2.9 in the Home country and 1.3 in the Foreign country.

There is however an important caveat. Models of the monetary transmission mechanism that attempt to reproduce the properties of historical time series may significantly overstate the degree of structural inflation persistence. This is because the inflationary inertias observed in the data may partially result from a slow learning process during the transition from high to low inflation regimes. ${ }^{35}$ In light of these considerations, estimates of $\phi_{W}$ and $\phi_{Q}$ based on historical episodes of disinflation should be expected to be biased upwards. Short of strong empirical evidence about the magnitude of this bias, we have reduced these parameters in half to establish a benchmark calibration of the model (see Table 1). Based on such parameterization of nominal rigidities, the sacrifice ratio is 2.0 in the Home country and 0.9 in the Foreign country (Table 4 ).

As a final check on the calibration of the system, we compared the impulse response functions of the model with the VAR estimates by Altig and others (2003) for the U.S. economy. The dashed lines in Figure 4 report the impulse responses (and confidence bands) for the VAR while the solid line reports the responses in our model when the same interest rate path is imposed on the Foreign economy for the first 8 quarters of the simulation horizon. As can be seen in the Figure, with the exception of the impact responses, our results generally fit within the confidence bands for output, consumption, investment and the price level. It is noteworthy that our price level declines monotonically over time but the VAR's price level increases somewhat over the first year of the shock. This may reflect the fact that different prices indices are reported from the VAR (the GDP deflator) and for our model (the consumption deflator), as a result of which the VAR may have less feedback from the real exchange rate. ${ }^{36}$

\footnotetext{
${ }^{35}$ See Erceg and Levin (2001) and Laxton and N'Diaye (2002).

${ }^{36}$ Altig and others (2003) emphasize that the initial effect of a rise in interest rates may be to raise marginal costs, thus explaining why the price level needs to rise temporarily before declining.
} 


\section{Simulation results}

This section focuses on how differing levels of competition affect macroeconomic performance. Increases in competition feed into output and demand as they reduce the ability of workers and firms to exploit market power by restricting the supply of goods and labor. As a result, a greater level of competition implies a higher level of real output, investment, and consumption. The rest of the world also benefits, as greater output in the Home country leads to an increase in the supply of exports to the Foreign country, and the induced depreciation in the Home terms of trade boosts real incomes and consumption abroad. In addition, as explained in the discussion of equation (19) above, greater competition makes it easier for the monetary authorities to stabilize domestic output and inflation, leading to less structural inflation persistence.

\subsection{Effects of higher markups on economic activity}

The impact of changing markups on the long-run levels of economic activity are shown in Figure 5. Starting from a situation in which both labor and product markets are essentially in competitive equilibrium, with a markup of $1 / 2$ percent (implying underlying elasticities of substitution $\psi$ and $\theta$ equal to 200), competition in the product and labor markets is reduced by increasing the relevant markup in increments of 5 percentage points to a final value of around 55 percent (implying underlying elasticities of around 3, almost a hundred-fold lower than the initial values). In all of these simulations, the other markups at home and abroad are held at their baseline values reported in Table $4 .{ }^{37}$

In analyzing these simulations, it is worth recalling the thought experiments being performed. Lower competition across firms (lower $\theta$ ) raises the price markup as these firm reduce output to exploit their less elastic demand curves. The contraction in output affects

\footnotetext{
${ }^{37}$ This ceteris paribus approach downplays the fact that lack of competition in product markets tends to lead to higher wage markups, implying that the two markups are generally not independent of each other: see Jean and Nicoletti (2002) and the discussion in Section 4.4.
} 
capital more than labor effort (hereafter assumed to be equivalent to hours worked) as in the long run labor is the less elastic resource. By contrast, lower competition in labor markets (lower $\psi$ ) allows workers to exploit their greater market power by reducing hours worked, as a result of which firms adjust their capital stock to remain efficient. In addition, the change in consumption is closely allied to the change in labor effort as, in steady state, the disutility of work has to be equated with the benefits of consumption (adjusted by the appropriate relative prices).

International spillovers depend crucially on the appreciation in the exchange rate as competition falls. This appreciation reflects the reduction in availability of Home goods as opposed to Foreign goods and the impact on the overall propensity to import stemming from shifts in spending (investment has a higher foreign component than consumption). For both reasons, spillovers are larger for product market reforms. This favorable terms of trade effect cushions the impact on consumption at home and exacerbates it abroad.

These considerations shed light on the simulations reported in Figure 5. The first feature to note is that higher markups in either market (and hence lower levels of competition) lead to mildly concave reductions in output and consumption at home and abroad. In the case of product markets, for example, an increase in the price markup from half a percent to five-and-a-half percent reduces output by 3.5 percent, while a similar increase from 50 to 55 percent reduces output by 1.9 percent. ${ }^{38}$ The costs associated with similar changes in wage markups are around half of these values. Given that wages comprise around two-thirds of costs, this implies that an increase in goods prices coming from greater competition across firms is somewhat more detrimental to output than an equivalent increase in costs coming from labor markets. An increase in the price markup has a particularly deleterious effect on the capital stock, which falls by 50 percent as the markup rises from zero to one-half, about double the reduction in output. Hours worked also decline, but by about two-thirds

\footnotetext{
${ }^{38}$ This concavity stems largely from the fact that a percentage point increase in the markup has a smaller percentage increase on overall prices or wages as the markup itself increases.
} 
of the fall in output. Consumption is reduced by a similar amount as lower domestic output and the fall in investment leads to a favorable terms of trade effect, with the exchange rate appreciating by some 15 percent.

Turning to the Foreign country, when the Home price markup rises from zero to onehalf output falls by around 2 percent (less than one-tenth of the reduction in the Home country) as the demand for exports falls and the terms of trade become more unfavorable. As a result of the latter effect, the fall in foreign consumption is larger than in output, and indeed the ratio of the decline in Foreign to Home consumption is around one-fifth, double the one-tenth figure for output. In short, a lack of product market competition has significant consumption spillovers to the rest of the world.

The effects of an increase in the wage markup of a similar magnitude produces a significantly different response in domestic inputs, consumption, and spillovers to the rest of the world. For an equivalent rise in the markup, output falls by under half as much. Labor effort, investment, and consumption all fall by similar amounts to output. The impact on consumption partly reflects the more limited real exchange rate appreciation, as the response of output, investment, and goods prices is more muted than when price markups increase by the same amount. The more limited exchange rate appreciation also constrains spillovers to the rest of the world, with Foreign consumption falling by only about one-tenth of its domestic equivalent.

\subsection{Effects of higher markups on sacrifice ratios}

Changes in product and labor market competition also have a significant impact on the flexibility of monetary policy. A useful metric is provided by the sacrifice ratio, i.e. the cumulative annual output gap that is required to permanently reduce the inflation rate by

one percentage point. Intuitively, monetary policy is easier to operate if the output losses associated with changing inflation are small.

Increases in the wage markup have a greater impact on the sacrifice ratio than equivalent 
changes in product markets. Figure 5 graphs the relationship between markups in goods and labor markets and the sacrifice ratio. The differences in impact of the two markups are substantial for low levels of the markup but erode as the markups increase, moving to near equality at markups of around 50 percent. This reflects the fact that the relationship is convex for price markups and concave for wage markups.

The greater sensitivity of wage-price flexibility to labor market competition comes from the fact that labor is the less elastic resource, and hence its price responds more in the presence of market power. The bottom line of this analysis is labor market inefficiencies have a smaller impact on long-term output than equivalent product market inefficiencies but, for reasonable parameters, the opposite is true for monetary policy flexibility. These differences largely reflect the fact that firms face direct competition from abroad while labor does not. Both effects create negative spillovers to the rest of the world, either through lower demand and a less favorable terms of trade (in the case of output) or a lower ability to stabilize domestic output (in the case of monetary policy). ${ }^{39}$

\subsection{Sensitivity analysis}

We now examine the sensitivity of these results to changes in key parameters. Figure 6 reports the results from reducing the Frisch elasticity of labor supply from 0.33 to 0.15 , closer to the mean of microeconomic estimates but further away from the values generally used in real business cycle models, as discussed above. Compared to the baseline case, the more limited labor supply response approximately halves the impact of changes in the wage markup on both domestic and foreign variables. For the price markup, the equivalent declines are one-quarter to one-third, reflecting the greater importance of reductions in investment in this case. The impact on the sacrifice ratio also decreases, particularly as regards the wage

\footnotetext{
${ }^{39}$ Andrés, Ortega and Vallés (2003) emphasize that the relative degree of market competition across countries is a crucial factor governing price responses to shocks. Small deviations in the degree of competition may be responsible for temporary inflation differentials of up to 28 basis points when the economies are subject to a common monetary policy shock.
} 
markup, as lower flexibility in labor supply translates into more accommodation through wages.

The equivalent deep parameter for firms is the elasticity of substitution between labor and capital. Figure 7 shows the results from shifting this parameter down by 0.1 in both countries. ${ }^{40}$ This change has little impact on the simulations, particularly those examining shifts in the wage markup. In the simulations of alternative price markups, it leads to a mildly larger fall in hours worked and smaller reduction in investment than in the base case, resulting in a slightly larger reduction in domestic consumption and smaller consumption spillovers to the rest of the world. Changes in this elasticity also have only marginal effects on the sacrifice ratio compared to the base case. The intuition for these small effects is that capital is a reproducible factor of production while labor supply is much more constrained, so that changes in the level of substitutability between capital and labor do not impact capital inputs significantly.

Next, changes in the degree of substitutability between domestic and foreign goods were examined. Figure 8 reports the results when this elasticity is lowered from the baseline value of 2.5 to 1.5, moving it toward the values found in macroeconomic studies and away from those typical in microeconomic work. As might be expected, the main impact of decreased substitutability between domestic goods and imports is to increase the exchange rate response to changes in markups. This, in turn, increases spillovers to the rest of the world through its impact on purchasing power at home and abroad. Indeed, both the appreciation of the real exchange rate and the impact on foreign consumption doubles compared to that in the baseline, while the ratio of the change in Foreign to Home consumption rises by even more, as the appreciation cushions some of the impact on Home consumers.

Finally, the intertemporal elasticity of substitution on consumption was reduced in both countries to unity (0.99 to be exact), corresponding to the log-utility value used in many

\footnotetext{
${ }^{40}$ This is a more limited shift in value compared to the base case than for the other parameters, as larger changes in this coefficient require a recalibration of other parts of the model.
} 
other papers. As discussed earlier, this switch has significant implications for the shortterm consumptions dynamics of the model. It turns out, however, that this change has a relatively limited impact on how shifts in markups affect long-term activity, with domestic consumption losses from higher markups being reduced by 15-20 percent and their foreign counterparts by more like 30 percent (Figure 9).

To summarize, with the important exception of the Frisch elasticity, changing key parameters in the rest of the model generally has only negligible effects on the impact of changes in competition on the domestic economy, but alter the international spillovers significantly. The intuition is that in the Home economy changes in markups have a first-order effect which tends to dominate, but the spillovers to the Foreign country come through indirect channels which are much more sensitive to the specification of the rest of the model. The Frisch elasticity is an exception as it directly affects the degree to which workers need to constrain their labor input to achieve a desired rise in markups, and hence has a first-order effect in the simulations.

\subsection{How much is a lack of competition costing the euro area?}

The analysis above can be applied to gauge the detrimental effects of low levels of competition in the euro area on the euro area itself and the rest of the world. The first stage in this process is to calculate reasonable estimates of price and wage markups from existing empirical work. A number of authors have looked at price markups by sector following the initial work on U.S. manufacturing by Hall (1988). But data for U.S. manufacturing may be atypical for at least two reasons. The United States has a lower regulatory burden than other countries, implying more competitive markets and lower markups, and manufacturing is probably more competitive than other sectors of the economy because of the high level of penetration by foreign producers. To get a broader view of markups, we use results from Martins, Scarpetta, and Pilat (1996) who estimate price markups across a wide range of countries and sectors using the methodology of Roeger (1995). Weighting reported markups 
by value added across sectors produces an estimated average markup of 23 percent in the United States and 35 percent in the euro area. These are considerably higher than the estimates for manufacturing of 15 and 19 percent, respectively. ${ }^{41}$

Earlier calibrations of wage markups have tended to look at evidence on elasticities of demand in the United States (see e.g. Smets and Wouters, 2002b). We take a different approach to estimating these wage markups, based on observed wage differentials across industries in different countries after controlling for other factors such as skill levels of the work force and age of workers, as reported in Jean and Nicoletti (2002). The wage markup is estimated by comparing wages in sectors in which labor is likely to have relatively little bargaining power to the average wage across the economy as a whole. The three sectors in which labor was assumed to have little bargaining power were textiles, worn apparel, and leather, all fragmented industries facing stiff competition from abroad. The results imply a wage markup of around 16 percent for the United States and around 24 percent for the euro area (based on GDP-weighted data for France, Italy, Austria, Belgium, Greece, and Ireland).${ }^{42}$

Jean and Nicoletti (2002) also find that regulation in product markets is linked to higher wage markups, implying that labor is able to capture some of the rents accruing from lower competition due to regulation. This suggests that the markups on wages and prices are linked to some extent, although the wage premium can also depend upon numerous other factors, including whether the industry is in the private or public sector. In fact, regulation drives up relative wages in the private sector, but drives down relative wages when the industry is publicly owned. The later effect is large - for a given level of regulation the

\footnotetext{
${ }^{41}$ In addition, Martins, Scarpetta and Pilat (1996) note that manufacturing markups are often lower in homogeneous industries, characterized by low R\&D spending, than differentiated industries where such spending is higher, and this difference may reflect the return to innovation. Simple calculations suggest that the markup for homogeneous manufacturing industries is about 11 percent in the United States compared with 19 percent in the euro area, with little impact on the economy-wide markups quoted above.

${ }^{42}$ Germany is not included in the study. Spain is also excluded, as mentioned in the text, as the high use of part-time workers reduces the reliability of the results.
} 
coefficient changes from 0.2 to minus 0.35 - possibly reflecting underlying inefficiencies associated with public ownership of commercial industries. This implies that the wage premiums due to high levels of regulation and hence low levels of competition may be larger than these numbers suggest for the euro area (the numbers for the United States are essentially unaffected, given the low level of public ownership). Calculating the bias requires assumptions about the degree of regulatory impediments in the euro area and level of public ownership. Back of the envelope calculations suggest, however, that it is probably of the order of 0.06 , a number we adopt. ${ }^{43}$

Based on these results, the wage markup was set at 16 percent for the United States and 30 percent for the euro area, and the price markup at 23 percent for the United States and 35 percent for the euro area (see Table 4). As a further check, we also looked at the estimates of overall differentials for a large number of disaggregated manufactured goods across countries reported in Bradford and Lawrence (2003). Their empirical results yielded an estimate of the overall gap between marginal costs and prices of $15-20$ percent in the United States and 50 percent or so in the euro area. These numbers are broadly consistent with our assumed values of wage and price mark-ups. Other parameters are set at their baseline levels.

The long-term effects, summarized in Table 5, are that if the euro area increased competitiveness in both labor and product markets to U.S. levels real output would rise by $12 \frac{1}{2}$ percent, with the capital stock increasing by over double that of hours worked (over 20 percent compared to 10 percent). The output and labor input spillovers to the rest of the world are relatively muted (under 1 percent), so that the rise in relative output represents over half of the gap in per capita GDP and labor utilization between the two regions (see

\footnotetext{
${ }^{43}$ Assume that the average regulatory burden in the public sector in the euro area is larger than the economy as a whole by around 1 1/2 (see Figure 1 in Jean and Nicoletti (2002)) and that such activity makes up 5-10 percent of the euro area economy. The bias is equal to ( $11 / 2$ (additional regulatory burden) times $(0.2+0.35)$ (bias in the coefficient on regulation) times 0.05 or 0.1 (proportion of activity in public sector) divided by 0.95 or 0.9 (proportion of activity not in public sector), which given a range of $0.04-0.09$.
} 
OECD (2003), Figure 1.1). The effects on consumption are more evenly spread, with an increase in consumption of over 8 percent in the euro area and $1 \frac{1}{4}$ percent in the United States, reflecting the real depreciation of the euro of some 5 percent. There is also a fall of about one-third in the sacrifice ratio, from 2 to 1.4 (see Table 6$).{ }^{44}$ In short, an analysis of these conventional macroeconomic indicators would suggest that greater competition in the euro area will be felt in both the euro area and the rest of the world.

Tables 5 and 6 also report results when the product and wage markups are changed separately. Greater product market competition has larger effects on activity than reducing labor market rigidities, with these differences being much starker for investment, output, and international spillovers than for consumption or labor effort. In the case of the sacrifice ratio, the impact of product and labor market reforms are the same, reflecting the relatively large effect on domestic nominal rigidities discussed above.

An important advantage of a choice-theoretic model with explicit microfoundations is that the costs and benefits of a change in competition can be evaluated directly by computing the change in consumer welfare, measured in consumption equivalents. ${ }^{45}$ More competition-friendly policies have two effects on welfare: a positive one stemming from higher consumption, and an offsetting reduction attributable to higher levels of labor effort. This is obviously important in the simulation above, as both consumption and labor effort in the euro area rise by the same amount ( 8.3 percent). However, as shown in Table 5 the net effect on welfare is positive (2.4 percent in terms of consumption equivalents) because

\footnotetext{
${ }^{44}$ This remains above the 0.9 estimate for the United States, as the euro area has higher costs of adjustment.

${ }^{45}$ Denoting $C$ and $\ell$ as the baseline levels for consumption and labor effort, and $C_{n e w}$ and $\ell_{n e w}$ as the new steady-state levels after the markup change, the consumption equivalent $C_{e q}$ is defined implicitly by $\mathcal{W}\left(C_{e q}, \ell\right)=\mathcal{W}\left(C_{n e w}, \ell_{n e w}\right)$, that is a measure of the permanent change in consumption required to achieve the new level of utility holding labor effort constant at its original (baseline) steady-state value. Note that our model specification implies that the marginal utility (disutility) of consumption (labor effort) is independent of habit persistence parameters $b_{c}$ and $b_{\ell}$. When we compute the long-term effects of a change in markups on consumer welfare, the utility metrics also abstracts from habit persistence in either consumption or labor effort.
} 
the rise in utility associated with additional consumption is higher than the disutility from additional labor effort. From this welfare perspective, it can be seen that spillover benefits of reforms are about one half of the magnitude in the rest of the world (1.2 percent increase in welfare), as the effect of the increase in consumption is not significantly offset by the much smaller increase in hours worked (0.2). It can also be seen in the Table that about $3 / 4$ of these increases in welfare are attributable to product market reforms, and the remainder to more competitive labor markets.

\section{Conclusion}

This paper has examined the benefits from greater competition in product and labor markets using a choice-theoretic, general-equilibrium model of the global economy. Lower levels of competition are associated with significantly reduced output and consumption at home and abroad, with the spillovers in consumption being larger than those in output due to an appreciation in the domestic real exchange rate. In addition, lower levels of competition affect macroeconomic policies by increasing nominal inertia in the model. This reduces the flexibility of domestic monetary policy, making it more difficult for the central bank to stabilize the economy in the face of disturbances.

Our simulations produce plausible empirical estimates of the effects of structural polices to improve competition. Changes in goods and wage markups have significantly different effects on the economy. Greater competition across firms leads to a more marked rise in the capital stock and output, and larger benefits to the rest of the world. Indeed, in our base case parameterization, the rise in foreign consumption is some 20 percent of that at home. Greater competition in labor markets results in a more marked increase in hours worked, nominal flexibility, and somewhat smaller international spillovers. Experiments varying the value of key elasticities indicate that the impact on the home country are relatively robust, while the size of the international spillovers is more sensitive to the parameterization of the 
rest of the model.

Applying the model to the euro area, structural polices that increase competition toward U.S. levels (based on empirically estimated markups in both regions) are found to increase output in the euro area by some $12 \frac{1}{2}$ percent, and that in the United States by 1 percent. The implied change in relative output represents around half of the current difference in per capita GDP. The gains in consumption are more evenly spread, with euro area consumption rising by 8 percent and U.S. consumption up $1 \frac{1}{4}$ percent, in part because the euro depreciates against the dollar by some 5 percent. In both countries the net effect on welfare is positive, as gains from higher consumption more than offset losses from higher labor effort. Equally importantly, these policies also benefits European policymakers by reducing the distortions associated with nominal rigidities, thereby making monetary policies more effective. Indeed, the sacrifice ratio (defined here as the cumulative output cost of reducing inflation by one percentage point) falls by a third.

While structural policies are being viewed increasingly as a source of differences across countries, empirical estimates of their macroeconomic effects have to date been extremely limited. This paper represents a preliminary attempt to bridge the gap, by providing an explicit theoretical and empirical methodology to calculate the impact of more competitionfriendly reforms. At the same time, it should be emphasized that our exercise represents but an initial experiment. More work will have to be done to examine how robust our results are to varying structures and assumptions. For instance, the role of tax asymmetries could be analyzed in light of the results by Prescott (2003). In addition, one can think of many more structural policies whose effects could be examined along similar lines, for example trade liberalization. An ambitious and exciting agenda lies ahead. 


\section{References}

[1] Acemoglu, D., S. Johnson, and J. Robinson (2002). "Reversal of Fortunes: Geography and Institutions in the Making of the Modern World Income Distribution." Quarterly Journal of Economics, Vol. 117, November, pp. 1231-94.

[2] Altig, D., L. Christiano, M. Eichenbaum and J. Linde (2003). "Technology Shocks and Aggregate Fluctuations," Working Paper, Northwestern University.

[3] Andrés, J., E. Ortega and J. Vallés (2003). "Competition and Inflation Differentials in EMU," Working Paper, Bank of Spain, September.

[4] Baily, M. (2003). "A Radical Transformation of the European Economy," Working Paper, Washington, Institute for International Economics.

[5] Blanchard, O. (2004). "The Economic Future of Europe." Journal of Economic Perspectives, forthcoming.

[6] Bradford, S. and R. Lawrence (2003). "Paying the Price: The Cost of Fragmentation in International Markets," Working Paper, Harvard University.

[7] Chari, V.V., P. J. Kehoe, and E.R. McGrattan (2002). "Can Sticky Price Models Generate Volatile and Persistent Real Exchange Rates?" Review of Economic Studies 69, pp. 533-63.

[8] Cooley, T. and E. Prescott (1995). "Economic Growth and Business Cycles," in T. Cooley (ed.), Frontiers of Business Cycle Research, Princeton NJ: Princeton University Press.

[9] Corsetti, G., and P. Pesenti (2001). "International Dimensions of Optimal Monetary Policy," National Bureau of Economic Research Working Paper No.8230, April. 
[10] Devereux, M., and C. Engel (2003). "Monetary Policy in the Open Economy Revisited: Exchange Rate Flexibility and Price Setting Behavior." Review of Economic Studies 70, pp. $765-783$.

[11] Erceg, C., L. Guerrieri and C. Gust (2003). "SIGMA: A New Open Economy Model for Policy Analysis," Draft Paper prepared for the Annual Central Bank Modelers' Workshop, Amsterdam.

[12] Erceg, C. and A. Levin (2001). "Imperfect Credibility and Inflation Persistence," Working Paper, Board of Governors of the Federal Reserve System.

[13] European Commission (2002). "Better Functioning Labor and Product Markets," in European Economy No. 6/2000, Chapter 3, Brussels: European Commission.

[14] Fagan, G., J. Henry and R. Mestre (2001). "An Area-Wide Model (AWM) for the euro area," Working Paper No. 42, European Central Bank.

[15] Galí, J., M. Gertler, and J. D. López-Salido (2002). "Markups, Gaps, and the Welfare Costs of Business Fluctuations," National Bureau of Economic Research Working Paper No. 8850 , March.

[16] Galí, J., and T. Monacelli (2002). "Monetary Policy and Exchange Rate Volatility in a Small Open Economy," National Bureau of Economic Research Working Paper No. 8905, April.

[17] Hall, R. (1988). "The Relation Between Price and Marginal Cost in U.S. Industry." Journal of Political Economy, Vol. 96, pp. 921-947.

[18] Hall, R., and C. Jones (1999). "Why do Some Countries Produce So Much More Output per Worker than Others?" Quarterly Journal of Economics, Vol. 114 (February), pp. 83-116. 
[19] Ireland, P. (2001). "Sticky-Price Models of the Business Cycle: Specification and Stability." Journal of Monetary Economics 47, February, pp.3-18.

[20] Jean, S. and G. Nicoletti (2002). "Product market Regulation and Wage Premia in Europe and North America," OECD Economics Department Working Paper $\operatorname{ECO} / \operatorname{WKP}(2002) 4$.

[21] Kim, J. (2000). "Constructing and Estimating a Realistic Optimizing Model of Monetary Policy." Journal of Monetary Economics 45, April, pp. 329-359.

[22] Laxton, D., P. Isard, H. Faruqee, E. Prasad, and B. Turtleboom (1998). "MULTIMOD Mark III: The Core Dynamic and Steady-State Models," IMF Occasional Paper 164, Washington, DC: International Monetary Fund.

[23] Laxton, D., and P. N'Diaye (2002). "Monetary Policy Credibility and the Unemployment-Inflation Trade-off: Some Evidence from 17 Industrial Countries," Working Paper WP/02/220, International Monetary Fund.

[24] Laxton, D., and P. Pesenti (2003). "Monetary Policy Rules for Small, Open, Emerging Economies." Journal of Monetary Economics 50, July, pp. 1109-1146.

[25] MacFarlan, M., H. Edison, and N. Spatafora (2003). "Growth and Institutions," in World Economic Outlook, April, Chapter 3, Washington, DC: International Monetary Fund.

[26] Martins, J.O., S. Scarpetta, and D. Pilat (1996). "Mark-up Pricing, Market Structure and the Business Cycle." OECD Economic Studies 27 (II), pp.71-106.

[27] OECD (1997). OECD Report on Regulatory Reform. Paris: OECD.

[28] OECD (2003). The Sources of Economic Growth in OECD Countries. Paris: OECD. 
[29] Pesenti, P. (2004). "The IMF Global Economy Model (GEM): Theoretical Framework", Working Paper, International Monetary Fund, forthcoming.

[30] Prescott, E.C. (2003). "Why Do Americans Work So Much More Than Europeans?," Federal Reserve Bank of Minneapolis, Research Department Staff Report 231, November.

[31] Roeger, W. (1995). "Can Imperfect Competition Explain the Difference Between Primal and Dual Productivity Measures? Estimates for U.S. Manufacturing." Journal of Political Economy 103, April, pp.316-330.

[32] Rotemberg, Julio J. (1982). "Sticky Prices in the United States." Journal of Political Economy 90, December, pp.1187-1211.

[33] Schmitt-Grohe, S., and M. Uribe (2004). "Optimal Fiscal and Monetary Policy under Sticky Prices." Journal of Economic Theory, Vol. 114, February, pp.198-230.

[34] Sims, C. (2002). "The Role of Models and Probabilities in the Monetary Policy Process." Brookings Papers on Economic Activity, 2.

[35] Smets, F., and R. Wouters (2002a). "Openness, Imperfect Exchange Rate Pass-Through and Monetary Policy." Journal of Monetary Economics, Vol. 49, pp. 947-81.

[36] Smets, F., and Wouters (2002b). "An estimated stochastic dynamic general equilibrium model of the euro area," ECB Working Paper No. 171, August.

[37] Taylor, J. (1993). "Discretion Versus Policy Rules in Practice." Carnegie-Rochester Conference Series on Public Policy, Vol. 39, pp. 195-214.

[38] Woodford M. (2003). Interest and Prices. Foundations of a Theory of Monetary Policy. Princeton, NJ: Princeton University Press. 
Figure 1: The Structure of the Model

HOME COUNTRY

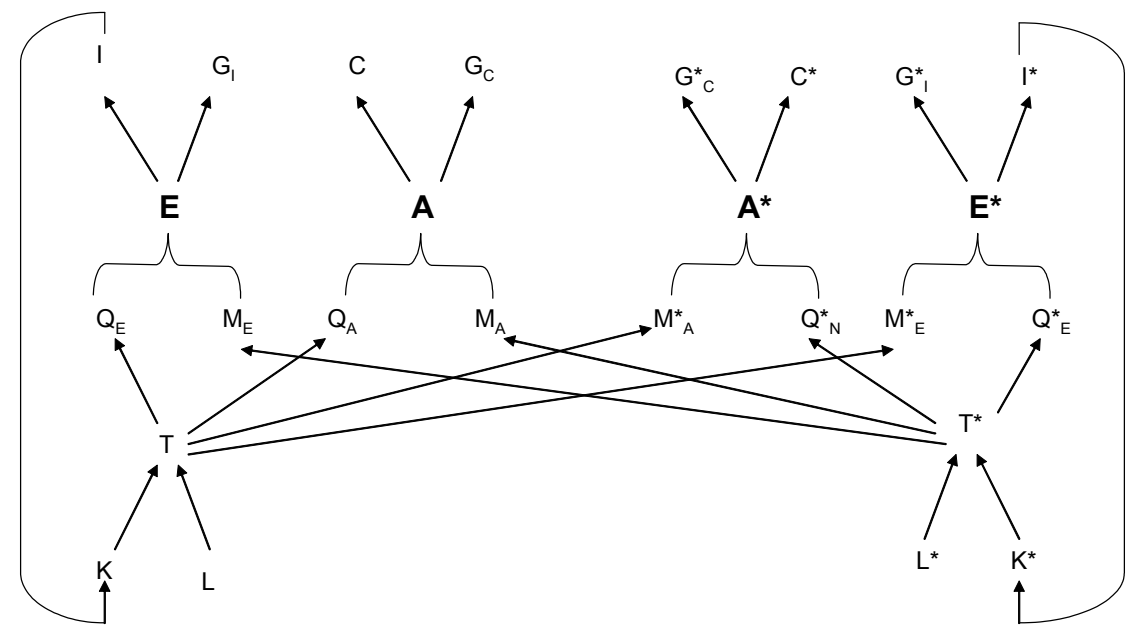


Table 1: Assumptions About Parameters and Steady-State Ratios

\begin{tabular}{|c|c|c|}
\hline Parameters: & Euro Area $(\mathrm{H})$ & Rest Ind. World (F) \\
\hline Discount Rate $\beta$ & $1.03^{-0.25}$ & $1.03^{-0.25}$ \\
\hline Depreciation Rate on Capital $\delta$ & 0.025 & 0.025 \\
\hline Habit Persistence Parameters $b_{c}\left(b_{\ell}\right)$ & $0.97(0.50)$ & $0.97(0.50)$ \\
\hline Intertemporal Elasticity of Substitution $1 / \sigma$ & 5.00 & 5.00 \\
\hline Elasticity of Input Substitution for Intermediate Goods $\xi$ & 0.80 & 0.70 \\
\hline Elasticity of Input Substitution for Consumption $\mu_{A}$ & 2.50 & 2.50 \\
\hline Elasticity of Input Substitution for Investment Goods $\mu_{E}$ & 2.50 & 2.50 \\
\hline Inverse of Frisch Elasticity of Labor Supply $\zeta$ & 3.00 & 3.00 \\
\hline Adjustment Cost Parameter for Imports of Consumption Goods $\phi_{M A}$ & 10.00 & 10.00 \\
\hline Adjustment Cost Parameter for Imports of Investment Goods $\phi_{M E}$ & 10.00 & 10.00 \\
\hline Adjustment Cost Parameter for Capital Accumulation $\phi_{I 1}$ & 1.00 & 1.00 \\
\hline Adjustment Cost Parameter for Investment Changes $\phi_{I 2}$ & 70.00 & 80.00 \\
\hline Adjustment Cost Parameter for Structural Wage Persistence $\phi_{W}$ & 1400 & 700 \\
\hline Adjustment Cost Parameter for Import Price Persistence $\phi_{M}$ & 0.00 & 0.00 \\
\hline Adjustment Cost Parameter for Domestic Prices Persistence $\phi_{Q}$ & 1400 & 700 \\
\hline Steady-State Ratios: & Euro Area $(\mathrm{H})$ & Rest Ind. World (F) \\
\hline Labor's Share & 0.47 & 0.58 \\
\hline Consumption Goods-to-GDP Ratio & 0.78 & 0.78 \\
\hline Private Consumption & 0.58 & 0.62 \\
\hline Government Consumption & 0.20 & 0.16 \\
\hline Investment Goods-to-GDP Ratio & 0.22 & 0.22 \\
\hline Private Investment & 0.19 & 0.19 \\
\hline Government Investment & 0.03 & 0.03 \\
\hline Imports-to-GDP Ratio & 0.18 & 0.13 \\
\hline Consumption Goods & 0.05 & 0.06 \\
\hline Investment Goods & 0.13 & 0.07 \\
\hline
\end{tabular}


Table 2: A Comparison of the Simulated Monetary Transmission Mechanism with the ECB's Area-Wide Model

(Responses to a 100 Basis Point Interest Rate Hike)

\begin{tabular}{|l|l|l|l|l|l|l|l|l|l|l|}
\hline \multicolumn{2}{|c|}{} & \multicolumn{2}{l}{ Quarter } \\
\hline Variable: & Model: & Sum & 1 & 2 & 3 & 4 & 5 & 6 & 7 & 8 \\
\hline Real GDP: & Home & -2.3 & -0.2 & -0.3 & -0.3 & -0.4 & -0.4 & -0.3 & -0.3 & -0.2 \\
\hline & AWM & -2.0 & -0.1 & -0.2 & -0.2 & -0.3 & -0.3 & -0.3 & -0.3 & -0.3 \\
\hline Consumption: & Home & -2.0 & -0.1 & -0.2 & -0.3 & -0.3 & -0.3 & -0.3 & -0.2 & -0.2 \\
\hline & AWM & -1.9 & -0.0 & -0.2 & -0.2 & -0.3 & -0.4 & -0.3 & -0.3 & -0.3 \\
\hline Investment: & Home & -7.5 & -0.5 & -0.9 & -1.1 & -1.2 & -1.2 & -1.0 & -0.9 & -0.7 \\
\hline & AWM & -7.8 & -0.1 & -0.5 & -0.8 & -1.2 & -1.5 & -1.4 & -1.3 & -1.2 \\
\hline Exports: & Home & -1.3 & -0.1 & -0.2 & -0.2 & -0.2 & -0.2 & -0.2 & -0.1 & -0.1 \\
\hline & AWM & -1.6 & -0.1 & -0.2 & -0.3 & -0.4 & -0.3 & -0.2 & -0.2 & -0.1 \\
\hline Imports: & Home & -3.3 & -0.2 & -0.4 & -0.5 & -0.6 & -0.5 & -0.4 & -0.3 & -0.3 \\
\hline & AWM & -4.9 & -0.2 & -0.5 & -0.7 & -0.9 & -0.9 & -0.7 & -0.6 & -0.6 \\
\hline Real Exchange Rate: & Home & 3.5 & 1.2 & 1.0 & 0.7 & 0.4 & 0.2 & 0.0 & -0.0 & -0.0 \\
\hline & AWM & -1.0 & 0.5 & 0.3 & 0.0 & -0.2 & -0.5 & -0.4 & -0.4 & -0.3 \\
\hline CPI & Home & -0.5 & -0.0 & -0.0 & -0.0 & -0.1 & -0.1 & -0.1 & -0.1 & -0.1 \\
\hline & AWM & -0.4 & -0.0 & -0.0 & -0.0 & -0.0 & -0.1 & -0.1 & -0.1 & -0.1 \\
\hline
\end{tabular}


Table 3: A Comparison of the Simulated Monetary Transmission Mechanism with the Federal Reserve Board's FRB-US Model

(Responses to a 100 Basis Point Interest Rate Hike)

\begin{tabular}{|l|l|l|l|l|l|l|l|l|l|l|}
\hline \multicolumn{1}{|l}{} & \multicolumn{2}{l}{ Quarter } \\
\hline Variable: & Model: & Sum & 1 & 2 & 3 & 4 & 5 & 6 & 7 & 8 \\
\hline Real GDP: & Foreign & -2.3 & -0.2 & -0.3 & -0.4 & -0.4 & -0.4 & -0.3 & -0.2 & -0.2 \\
\hline & FRB-US & -2.7 & -0.1 & -0.2 & -0.3 & -0.4 & -0.4 & -0.5 & -0.4 & -0.4 \\
\hline Consumption: & Foreign & -1.9 & -0.1 & -0.2 & -0.3 & -0.3 & -0.3 & -0.2 & -0.2 & -0.1 \\
\hline & FRB-US & -2.6 & -0.1 & -0.2 & -0.3 & -0.4 & -0.4 & -0.4 & -0.4 & -0.4 \\
\hline Investment: & Foreign & -6.3 & -0.5 & -0.8 & -1.0 & -1.1 & -1.0 & -0.8 & -0.6 & -0.4 \\
\hline & FRB-US & -5.6 & -0.1 & -0.5 & -0.8 & -0.9 & -1.0 & -0.9 & -0.8 & -0.6 \\
\hline Exports: & Foreign & -0.8 & -0.1 & -0.1 & -0.2 & -0.2 & -0.1 & -0.1 & -0.0 & 0.0 \\
\hline & FRB-US & -1.8 & -0.0 & -0.1 & -0.1 & -0.2 & -0.3 & -0.3 & -0.4 & -0.4 \\
\hline Imports: & Foreign & -2.0 & -0.2 & -0.3 & -0.4 & -0.4 & -0.3 & -0.3 & -0.2 & -0.1 \\
\hline & FRB-US & -2.9 & -0.1 & -0.2 & -0.4 & -0.5 & -0.5 & -0.5 & -0.4 & -0.3 \\
\hline Real Exchange Rate: & Foreign & 2.2 & 1.1 & 0.9 & 0.6 & 0.3 & -0.0 & -0.2 & -0.2 & -0.2 \\
\hline & FRB-US & 4.3 & 1.0 & 0.9 & 0.7 & 0.6 & 0.4 & 0.3 & 0.2 & 0.2 \\
\hline CPI & Foreign & -1.5 & -0.0 & -0.1 & -0.1 & -0.2 & -0.2 & -0.3 & -0.3 & -0.4 \\
\hline & FRB-US & -1.7 & -0.0 & -0.1 & -0.1 & -0.2 & -0.2 & -0.3 & -0.4 & -0.4 \\
\hline
\end{tabular}

Table 4: Baseline Estimates of Markups and Sacrifice Ratios for the Euro Area and the United States

\begin{tabular}{|l|l|l|c|c|l|}
\hline & \multicolumn{4}{|l|}{ Markups and Elasticities of Substitution } & \multicolumn{2}{l|}{ Sacrifice Ratio } \\
\hline & Price Markup & Wage Markup & & & \\
\hline & $\theta /(\theta-1)$ & $\psi /(\psi-1)$ & $\theta$ & $\psi$ & \\
\hline euro area & 1.35 & 1.30 & 3.9 & 4.3 & 2.0 \\
\hline United States & 1.23 & 1.16 & 5.4 & 7.3 & 0.9 \\
\hline
\end{tabular}


Figure 2: Consumption Responses to a 4-Quarter 100 Basis Point Hike in Interest Rates Under Alternative Assumptions for Habit Persistence and Intertemporal Substitution

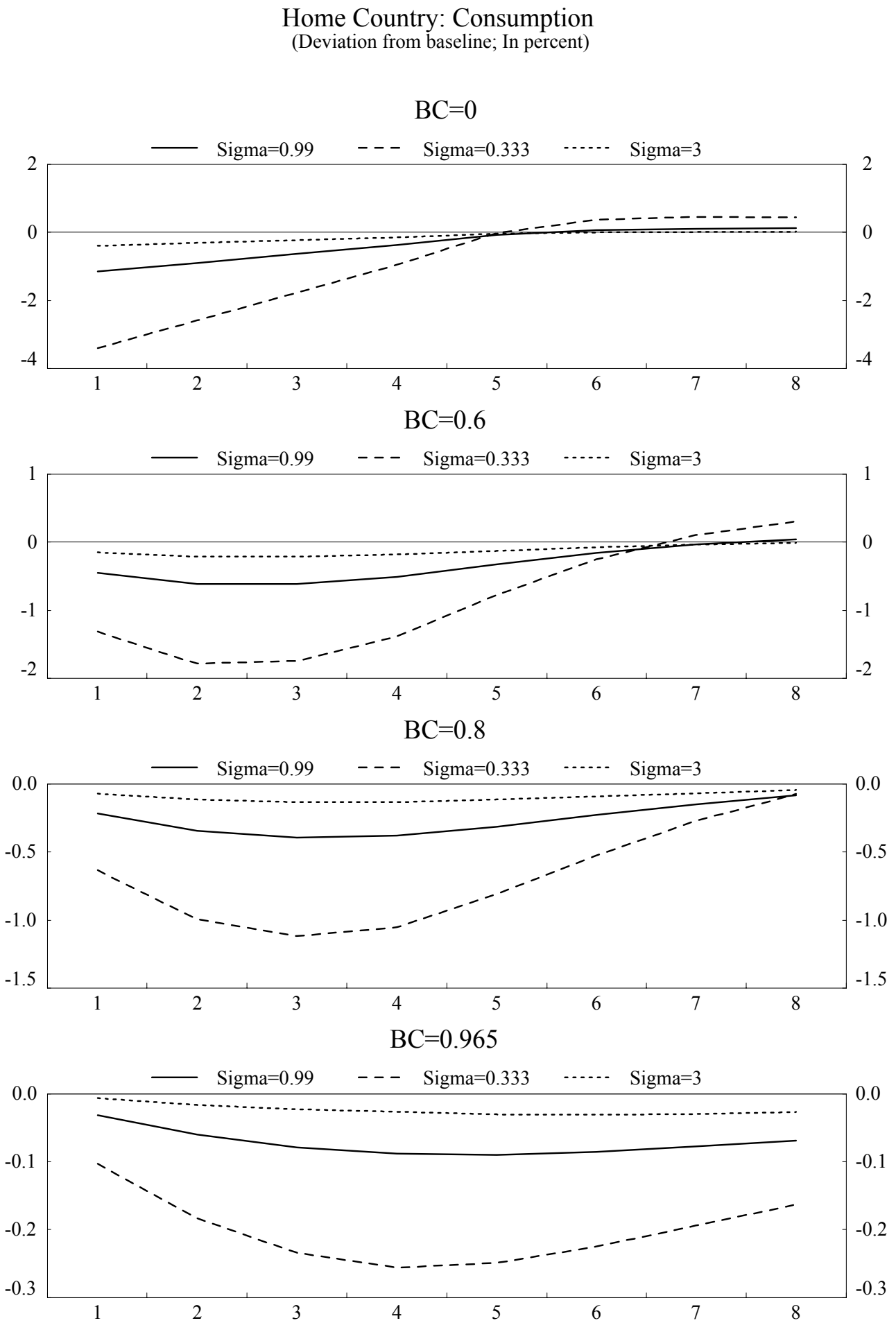


Figure 3: Output, Consumption and Labor Effort Responses to a Disinflation Shock Under Alternative Assumptions About Habit Persistence in Labor Effort

Home Country: Disinflation Shock

(Deviation from baseline; In percent)
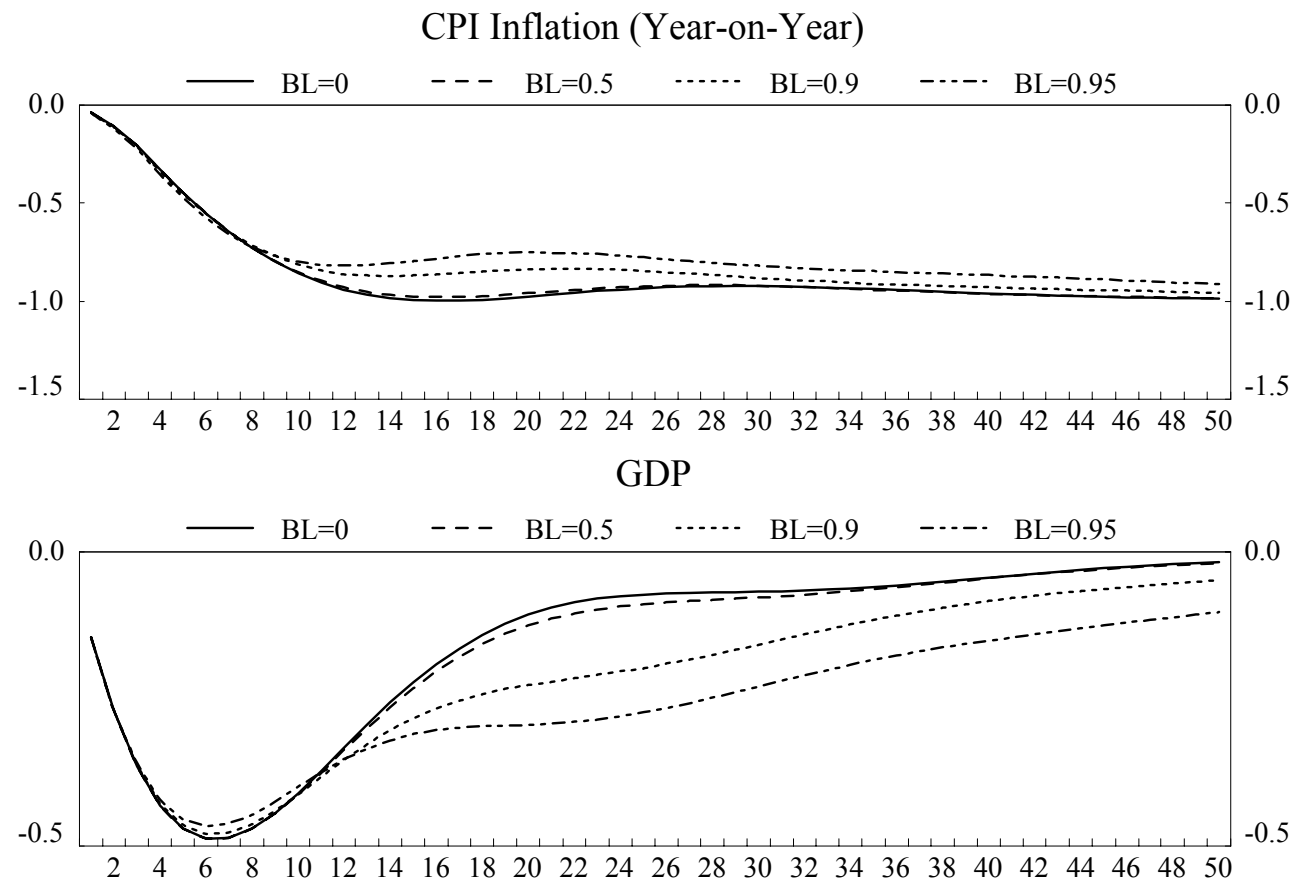

\section{Consumption}

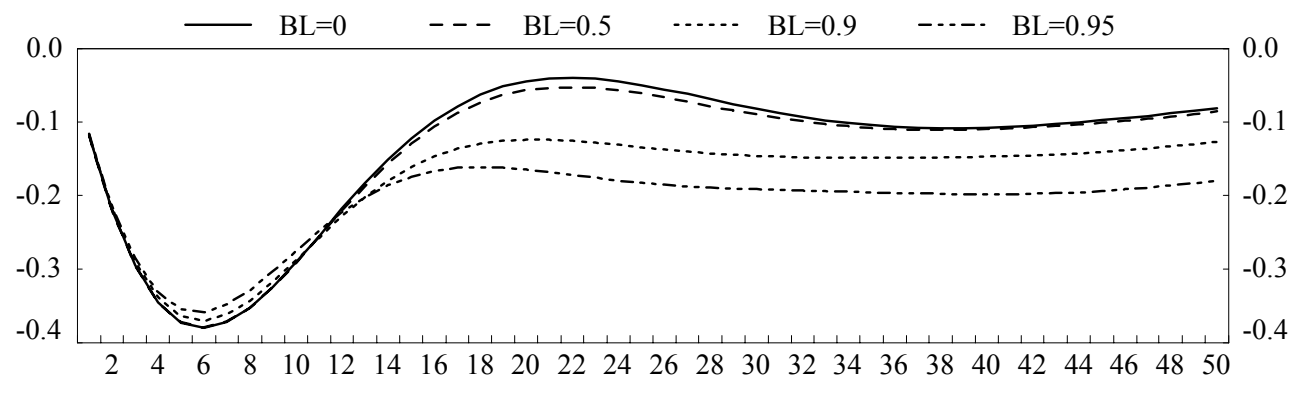

Labor Effort

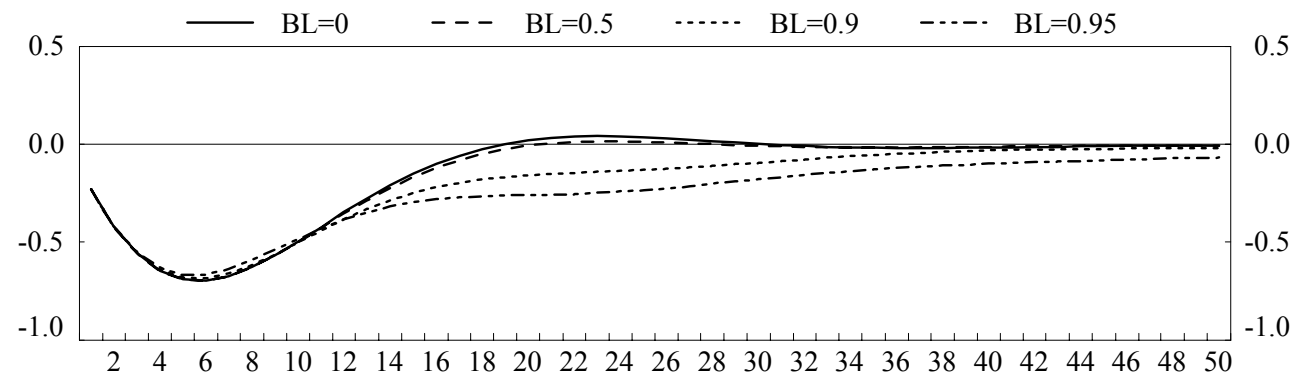


Figure 4: A Comparison of an Interest Rate Shock in the Model with VAR Estimates by Altig and others (2003)
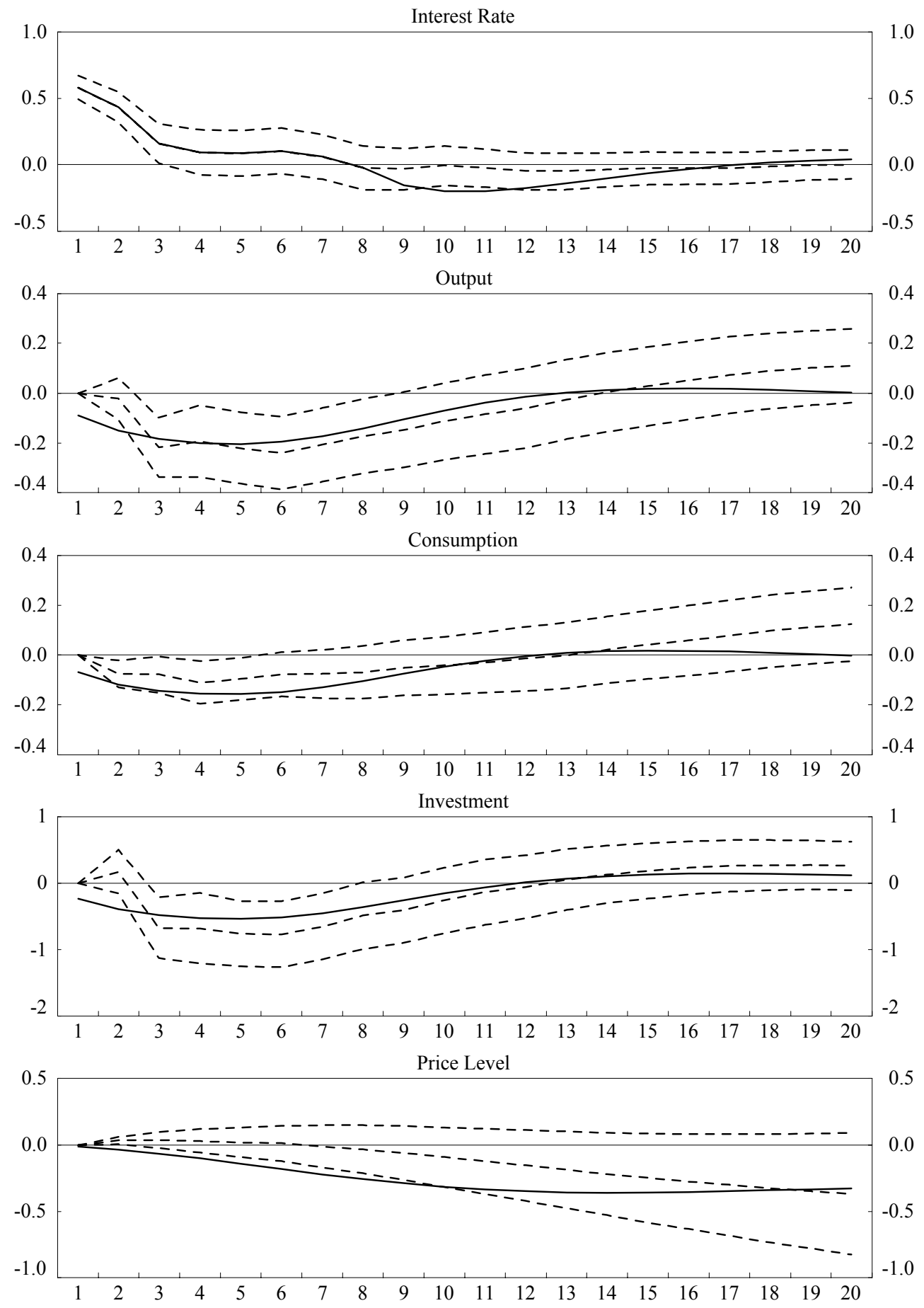
Figure 5: Effects of Different Price and Wage Markups on Sacrifice Ratios and Long-Run Economic Activity (BASE-CASE PARAMETERS)

Long-Run Effects of Different Price Markups and Wage Markups

$$
\begin{array}{lllllllllll}
1.055 & 1.105 & 1.155 & 1.205 & 1.255 & 1.305 & 1.355 & 1.405 & 1.455 & 1.505 & 1.555
\end{array}
$$

Home Country Long-run Effects of Higher Price Markups (In percent)

$\begin{array}{lrrrrrrrrrrr}\text { GDP } & -3.5 & -6.8 & -9.9 & -12.7 & -15.3 & -17.8 & -20.1 & -22.3 & -24.4 & -26.3 & -28.2 \\ \text { Consumption } & -2.0 & -3.9 & -5.9 & -7.7 & -9.6 & -11.4 & -13.1 & -14.8 & -16.5 & -18.1 & -19.6 \\ \text { Investment } & -7.2 & -13.7 & -19.4 & -24.6 & -29.2 & -33.4 & -37.2 & -40.7 & -43.9 & -46.8 & -49.5 \\ \text { Labor Effort } & -2.1 & -4.0 & -5.9 & -7.6 & -9.2 & -10.8 & -12.2 & -13.6 & -14.9 & -16.2 & -17.4 \\ \text { Real Exchange Rate } & -1.8 & -3.6 & -5.1 & -6.6 & -8.0 & -9.3 & -10.5 & -11.6 & -12.7 & -13.8 & -14.7\end{array}$

Real Exchange R

Spillover Effects on Foreign Country of Higher Price Markups in Home Country (In percent)

$\begin{array}{llllllllllll}\text { GDP } & -0.3 & -0.5 & -0.8 & -1.0 & -1.2 & -1.3 & -1.5 & -1.7 & -1.8 & -2.0 & -2.1 \\ \text { Consumption } & -0.4 & -0.9 & -1.2 & -1.6 & -1.9 & -2.2 & -2.5 & -2.8 & -3.0 & -3.2 & -3.5 \\ \text { Investment } & -0.2 & -0.4 & -0.6 & -0.8 & -0.9 & -1.1 & -1.2 & -1.4 & -1.5 & -1.6 & -1.7 \\ \text { Labor Effort } & -0.1 & -0.1 & -0.1 & -0.2 & -0.2 & -0.3 & -0.3 & -0.3 & -0.3 & -0.4 & -0.4\end{array}$

Home Country Long-run Effects of Higher Wage Markups (In percent)

\begin{tabular}{|c|c|c|c|c|c|c|c|c|c|c|c|}
\hline GDP & -1.5 & -2.8 & -4.1 & -5.3 & -6.5 & -7.6 & -8.6 & -9.6 & -10.5 & -11.4 & -12.3 \\
\hline Consumption & -1.4 & -2.6 & -3.8 & -5.0 & -6.0 & -7.1 & -8.0 & -9.0 & -9.9 & -10.7 & -11.5 \\
\hline Investment & -1.5 & -2.8 & -4.1 & -5.3 & -6.5 & -7.6 & -8.6 & -9.6 & -10.6 & -11.5 & -12.4 \\
\hline Labor Effort & -1.5 & -2.9 & -4.2 & -5.5 & -6.7 & -7.8 & -8.9 & -9.9 & -10.9 & -11.8 & -12.7 \\
\hline $\begin{array}{l}\text { Real Exchange Rate } \\
\text { (- appreciation) }\end{array}$ & -0.5 & -0.9 & -1.4 & -1.8 & -2.2 & -2.5 & -2.9 & -3.2 & -3.6 & -3.9 & -4.2 \\
\hline
\end{tabular}

Spillover Effects on Foreign Country of Higher Wage Markups in Home Country (In percent)

$\begin{array}{llllllllllll}\text { GDP } & -0.1 & -0.1 & -0.2 & -0.3 & -0.3 & -0.4 & -0.4 & -0.5 & -0.5 & -0.6 & -0.6 \\ \text { Consumption } & -0.1 & -0.2 & -0.3 & -0.4 & -0.5 & -0.6 & -0.7 & -0.8 & -0.9 & -0.9 & -1.0 \\ \text { Investment } & -0.1 & -0.1 & -0.2 & -0.2 & -0.3 & -0.3 & -0.3 & -0.4 & -0.4 & -0.5 & -0.5 \\ \text { Labor Effort } & -0.0 & -0.0 & -0.0 & -0.0 & -0.1 & -0.1 & -0.1 & -0.1 & -0.1 & -0.1 & -0.1\end{array}$

Long-Run Effects of Different Price Markups and Wage Markups

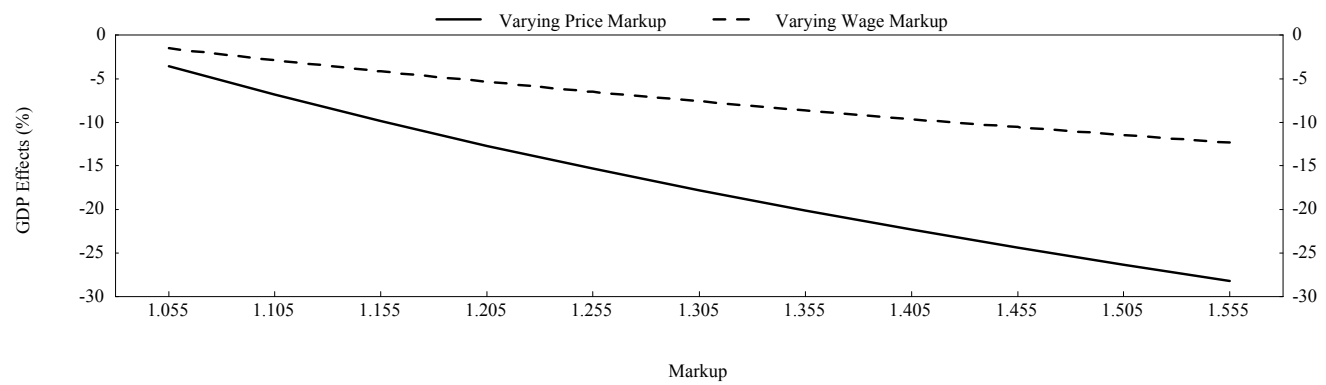

Sacrifice Ratios for Home Country Under Different Markups

\begin{tabular}{|c|c|c|c|c|c|c|c|c|c|c|c|c|}
\hline & 005 & 1.055 & 1.105 & 1.155 & 1.205 & 1.255 & 1.305 & 1.355 & 1.405 & 1.455 & 1.505 & 1.555 \\
\hline $\begin{array}{l}\text { Sacrifice Ratio } \\
\text { (Varying Price Markup) }\end{array}$ & 0.2 & 0.3 & 0.4 & 0.6 & 0.8 & 0.9 & 1.1 & 1.3 & 1.4 & 1.6 & 1.7 & 1.9 \\
\hline $\begin{array}{l}\text { Sacrifice Ratio } \\
\text { (Varying Wage Markup) }\end{array}$ & 0.2 & 0.5 & 0.8 & 0.9 & 1.1 & 1.2 & 1.3 & 1.4 & 1.5 & 1.6 & 1.7 & 1.8 \\
\hline
\end{tabular}


Figure 6: Effects of Different Price and Wage Markups on Sacrifice Ratios and Long-Run Economic Activity (BASE-CASE PARAMETERS WITH REDUCED FRISCH ELASTICITY $\zeta=1 / .15=6.7)$

Long-Run Effects of Different Price Markups and Wage Markups

$$
\begin{array}{lllllllllll}
1.055 & 1.105 & 1.155 & 1.205 & 1.255 & 1.305 & 1.355 & 1.405 & 1.455 & 1.505 & 1.555
\end{array}
$$

Home Country Long-run Effects of Higher Price Markups (In percent)

\begin{tabular}{|c|c|c|c|c|c|c|c|c|c|c|c|}
\hline GDP & -2.5 & -4.8 & -7.0 & -9.1 & -11.0 & -12.9 & -14.6 & -16.3 & -17.9 & -19.4 & -20.9 \\
\hline imption & -1 & -2.0 & -3.0 & -4.1 & -5.2 & -6.3 & -7.4 & -8.5 & -9.6 & & \\
\hline ent & -6 & -11.8 & 16.8 & 21.4 & -25.6 & -29.4 & -32.9 & -36.1 & -39.0 & -4 & 3 \\
\hline r Effort & -1 & -1.9 & -2.8 & -3. & -4.4 & -5 . & -5.9 & -6.6 & -7.3 & -7.9 & -8.5 \\
\hline eal Exchange Rate & -1.5 & -2.9 & -4.2 & -5.4 & -6.6 & -7.6 & -8.6 & -9.6 & -10.5 & -11.3 & -12.1 \\
\hline
\end{tabular}

(- appreciation)

Spillover Effects on Foreign Country of Higher Price Markups in Home Country (In percent)

$\begin{array}{llllllllllll}\text { GDP } & -0.2 & -0.4 & -0.6 & -0.7 & -0.9 & -1.0 & -1.1 & -1.3 & -1.4 & -1.5 & -1.6 \\ \text { Consumption } & -0.3 & -0.7 & -1.0 & -1.2 & -1.5 & -1.7 & -1.9 & -2.1 & -2.3 & -2.5 & -2.7 \\ \text { Investment } & -0.2 & -0.3 & -0.4 & -0.6 & -0.7 & -0.8 & -0.9 & -1.0 & -1.1 & -1.2 & -1.2 \\ \text { Labor Effort } & -0.0 & -0.0 & -0.1 & -0.1 & -0.1 & -0.1 & -0.1 & -0.1 & -0.1 & -0.1 & -0.2\end{array}$

Home Country Long-run Effects of Higher Wage Markups (In percent)

$\begin{array}{llllllllllll}\text { GDP } & -0.7 & -1.3 & -1.9 & -2.5 & -3.1 & -3.6 & -4.1 & -4.6 & -5.0 & -5.5 & -5.9 \\ \text { Consumption } & -0.6 & -1.2 & -1.8 & -2.3 & -2.9 & -3.4 & -3.8 & -4.3 & -4.7 & -5.1 & -5.5 \\ \text { Investment } & -0.7 & -1.3 & -1.9 & -2.5 & -3.1 & -3.6 & -4.1 & -4.6 & -5.1 & -5.5 & -6.0 \\ \text { Labor Effort } & -0.7 & -1.4 & -2.0 & -2.6 & -3.2 & -3.7 & -4.2 & -4.7 & -5.2 & -5.7 & -6.1 \\ \text { Real Exchange Rate } & -0.2 & -0.4 & -0.6 & -0.8 & -1.0 & -1.2 & -1.4 & -1.5 & -1.7 & -1.8 & -2.0 \\ \text { (- appreciation) } & & & & & & & & & & & \end{array}$

Spillover Effects on Foreign Country of Higher Wage Markups in Home Country (In percent)

$\begin{array}{llllllllllll}\text { GDP } & -0.0 & -0.1 & -0.1 & -0.1 & -0.1 & -0.2 & -0.2 & -0.2 & -0.2 & -0.2 & -0.3 \\ \text { Consumption } & -0.1 & -0.1 & -0.1 & -0.2 & -0.2 & -0.3 & -0.3 & -0.3 & -0.4 & -0.4 & -0.5 \\ \text { Investment } & -0.0 & -0.0 & -0.1 & -0.1 & -0.1 & -0.1 & -0.1 & -0.2 & -0.2 & -0.2 & -0.2 \\ \text { Labor Effort } & -0.0 & -0.0 & -0.0 & -0.0 & -0.0 & -0.0 & -0.0 & -0.0 & -0.0 & -0.0 & -0.0\end{array}$

Long-Run Effects of Different Price Markups and Wage Markups

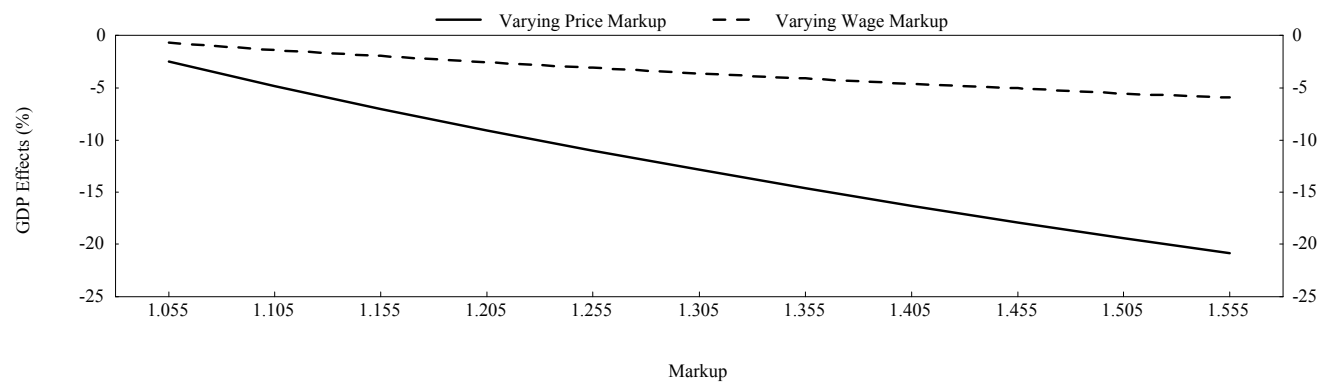

Sacrifice Ratios for Home Country Under Different Markups

$\begin{array}{llllllllllll}1.005 & 1.055 & 1.105 & 1.155 & 1.205 & 1.255 & 1.305 & 1.355 & 1.405 & 1.455 & 1.505 & 1.555\end{array}$

\begin{tabular}{|c|c|c|c|c|c|c|c|c|c|c|c|}
\hline $\begin{array}{l}\text { Sacrifice Ratio } \\
\text { (Varying Price Markup) }\end{array}$ & 0.1 & 0.2 & 0.3 & 0.5 & 0.6 & 0.8 & 0.9 & 1.0 & 1.2 & 1.3 & 1.5 \\
\hline $\begin{array}{l}\text { Sacrifice Ratio } \\
\text { (Varying Wage Markup) }\end{array}$ & 0.1 & 0.3 & 0.5 & 0.6 & 0.7 & 0.8 & 0.8 & 0.9 & 1.0 & 1.0 & 1.1 \\
\hline
\end{tabular}


Figure 7: Effects of Different Price and Wage Markups on Sacrifice Ratios and Long-Run Economic Activity (BASE-CASE PARAMETERS WITH ELASTICITY OF SUBSTITUTION BETWEEN CAPITAL AND LABOR REDUCED BY 0.10)

Long-Run Effects of Different Price Markups and Wage Markups

$\begin{array}{lllllllllll}1.055 & 1.105 & 1.155 & 1.205 & 1.255 & 1.305 & 1.355 & 1.405 & 1.455 & 1.505 & 1.555\end{array}$

Home Country Long-run Effects of Higher Price Markups (In percent)

\begin{tabular}{|c|c|c|c|c|c|c|c|c|c|c|c|}
\hline SDP & -3.5 & -6.7 & -9.7 & -12.5 & -15.1 & -17.6 & -19.9 & -22.1 & -24.2 & -26.2 & -28.1 \\
\hline Consumption & -2 & -4.1 & -6.1 & -8.0 & -9.9 & -11.7 & -13.5 & -15.3 & -16.9 & -18.6 & -20.2 \\
\hline Investment & -6.7 & -12.7 & -18.1 & -23.0 & -27.5 & -31.5 & -35.2 & -3 & -41.7 & -44.6 & -47.2 \\
\hline Effort & -2.1 & -4.1 & -6.0 & -7 . & -9.4 & -11.0 & -12 & & & -1 & -17.8 \\
\hline eal Exchange Rate & -1.7 & -3. & -4.9 & -6. & -7.6 & -8.9 & -10.1 & -11.2 & -12.3 & -13.3 & 14.2 \\
\hline
\end{tabular}

Spillover Effects on Foreign Country of Higher Price Markups in Home Country (In percent)

$\begin{array}{llllllllllll}\text { GDP } & -0.3 & -0.5 & -0.7 & -0.9 & -1.1 & -1.3 & -1.4 & -1.6 & -1.7 & -1.8 & -2.0 \\ \text { Consumption } & -0.4 & -0.8 & -1.2 & -1.5 & -1.8 & -2.1 & -2.4 & -2.6 & -2.9 & -3.1 & -3.3 \\ \text { Investment } & -0.2 & -0.4 & -0.5 & -0.7 & -0.8 & -0.9 & -1.0 & -1.1 & -1.3 & -1.3 & -1.4 \\ \text { Labor Effort } & -0.0 & -0.1 & -0.1 & -0.2 & -0.2 & -0.2 & -0.3 & -0.3 & -0.3 & -0.3 & -0.4\end{array}$

Home Country Long-run Effects of Higher Wage Markups (In percent)

\begin{tabular}{|c|c|c|c|c|c|c|c|c|c|c|c|}
\hline GDP & -1.5 & -2.8 & -4.1 & -5.3 & -6.5 & -7.6 & -8.6 & -9.6 & -10.5 & -11.4 & -12.3 \\
\hline Consumption & -1.4 & -2.6 & -3.8 & -5.0 & -6.0 & -7.1 & -8.0 & -9.0 & -9.9 & -10.7 & -11.5 \\
\hline Investment & -1.5 & -2.8 & -4.1 & -5.4 & -6.5 & -7.6 & -8.7 & -9.7 & -10.6 & -11.5 & -12.4 \\
\hline Labor Effort & -1.5 & -2.9 & -4.2 & -5.5 & -6.7 & -7.8 & -8.9 & -9.9 & -10.9 & -11.8 & -12.7 \\
\hline $\begin{array}{l}\text { Real Exchange Rate } \\
\text { (- appreciation) }\end{array}$ & -0.5 & -0.9 & -1.4 & -1.8 & -2.2 & -2.5 & -2.9 & -3.2 & -3.6 & -3.9 & -4.2 \\
\hline lover $\mathbf{F f f e c t s}$ & & & & & & & & & & & \\
\hline GDP & -0.1 & -0.1 & -0.2 & -0.3 & -0.3 & -0.4 & -0.4 & -0.5 & -0.5 & -0.6 & -0.6 \\
\hline Consumption & -0.1 & -0.2 & -0.3 & -0.4 & -0.5 & -0.6 & -0.7 & -0.8 & -0.9 & -0.9 & -1.0 \\
\hline Investment & -0.1 & -0.1 & -0.1 & -0.2 & -0.2 & -0.3 & -0.3 & -0.3 & -0.4 & -0.4 & -0.4 \\
\hline Labor Effort & -0.0 & -0.0 & -0.0 & -0.0 & -0.1 & -0.1 & -0.1 & -0.1 & -0.1 & -0.1 & 0.1 \\
\hline
\end{tabular}

Long-Run Effects of Different Price Markups and Wage Markups

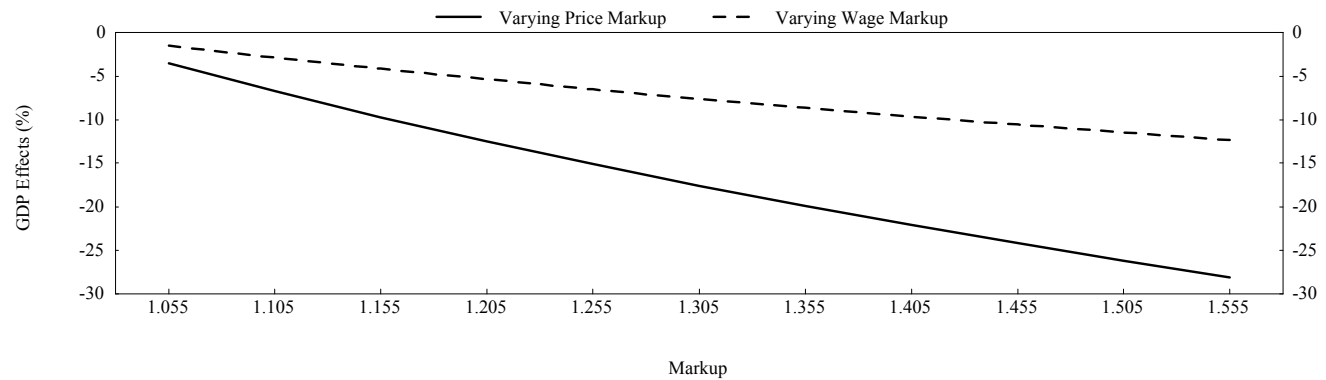

Sacrifice Ratios for Home Country Under Different Markups

$\begin{array}{llllllllllll}1.005 & 1.055 & 1.105 & 1.155 & 1.205 & 1.255 & 1.305 & 1.355 & 1.405 & 1.455 & 1.505 & 1.555\end{array}$

\begin{tabular}{|c|c|c|c|c|c|c|c|c|c|c|c|}
\hline $\begin{array}{l}\text { Sacrifice Ratio } \\
\text { (Varying Price Markup) }\end{array}$ & 0.2 & 0.3 & 0.5 & 0.6 & 0.8 & 1.0 & 1.2 & 1.4 & 1.6 & 1.7 & 1.9 \\
\hline $\begin{array}{l}\text { Sacrifice Ratio } \\
\text { (Varying Wage Markup) }\end{array}$ & 0.2 & 0.6 & 0.8 & 1.0 & 1.2 & 1.3 & 1.4 & 1.6 & 1.7 & 1.8 & 1.9 \\
\hline
\end{tabular}


Figure 8: Effects of Different Price and Wage Markups on Sacrifice Ratios and LongRun Economic Activity (BASE-CASE PARAMETERS WITH REDUCED IMPORT DEMAND ELASTICITIES $\left.\mu_{A}=\mu_{E}=1.5\right)$

\section{Long-Run Effects of Different Price Markups and Wage Markups}

$$
\begin{array}{lllllllllll}
1.055 & 1.105 & 1.155 & 1.205 & 1.255 & 1.305 & 1.355 & 1.405 & 1.455 & 1.505 & 1.555
\end{array}
$$

Home Country Long-run Effects of Higher Price Markups (In percent)

$\begin{array}{lccccccccccc}\text { GDP } & -3.4 & -6.5 & -9.4 & -12.1 & -14.7 & -17.1 & -19.3 & -21.4 & -23.4 & -25.3 & -27.1 \\ \text { Consumption } & -1.5 & -3.0 & -4.6 & -6.2 & -7.8 & -9.4 & -10.9 & -12.5 & -14.0 & -15.5 & -16.9 \\ \text { Investment } & -7.1 & -13.4 & -19.1 & -24.2 & -28.8 & -32.9 & -36.7 & -40.1 & -43.3 & -46.2 & -48.9 \\ \text { Labor Effort } & -2.1 & -4.0 & -5.8 & -7.5 & -9.1 & -10.7 & -12.1 & -13.5 & -14.8 & -16.0 & -17.2 \\ \text { Real Exchange Rate } & -3.7 & -7.0 & -10.0 & -12.7 & -15.2 & -17.6 & -19.7 & -21.7 & -23.6 & -25.3 & -26.9\end{array}$

(- appreciation)

Spillover Effects on Foreign Country of Higher Price Markups in Home Country (In percent)

\begin{tabular}{|c|c|c|c|c|c|c|c|c|c|c|c|}
\hline GDP & -0.6 & -1.1 & -1.5 & -2.0 & -2.4 & -2.7 & -3.1 & -3.4 & -3.7 & -4.0 & -4.3 \\
\hline mption & -0.9 & -1.7 & -2 & -3 & -3.9 & -4.5 & -5.1 & -5.6 & -6.1 & -6.6 & -7.0 \\
\hline Investment & -0.4 & -0.9 & -1.2 & -1.6 & -1.9 & -2.2 & -2.5 & -2.8 & -3.0 & -3.2 & -3.5 \\
\hline Labor Effort & -0.1 & ? & & & & & 06 & -06 & -0.7 & -0.7 & \\
\hline
\end{tabular}

Home Country Long-run Effects of Higher Wage Markups (In percent)

$\begin{array}{lrrrrrrrrrrr}\text { GDP } & -1.4 & -2.7 & -4.0 & -5.1 & -6.2 & -7.3 & -8.3 & -9.2 & -10.2 & -11.0 & -11.9 \\ \text { Consumption } & -1.2 & -2.3 & -3.4 & -4.4 & -5.4 & -6.3 & -7.2 & -8.0 & -8.8 & -9.6 & -10.3 \\ \text { Investment } & -1.4 & -2.7 & -4.0 & -5.2 & -6.3 & -7.4 & -8.4 & -9.3 & -10.3 & -11.1 & -12.0 \\ \text { Labor Effort } & -1.5 & -2.9 & -4.2 & -5.5 & -6.6 & -7.8 & -8.8 & -9.9 & -10.8 & -11.7 & -12.6 \\ \text { Real Exchange Rate } & -0.9 & -1.8 & -2.7 & -3.5 & -4.2 & -5.0 & -5.6 & -6.3 & -6.9 & -7.5 & -8.1 \\ \text { (- appreciation) } & & & & & & & & & & & \end{array}$

Spillover Effects on Foreign Country of Higher Wage Markups in Home Country (In percent)

$\begin{array}{llllllllllll}\text { GDP } & -0.1 & -0.3 & -0.4 & -0.5 & -0.6 & -0.8 & -0.9 & -1.0 & -1.1 & -1.2 & -1.2 \\ \text { Consumption } & -0.2 & -0.5 & -0.7 & -0.9 & -1.0 & -1.2 & -1.4 & -1.6 & -1.7 & -1.9 & -2.0 \\ \text { Investment } & -0.1 & -0.2 & -0.3 & -0.4 & -0.5 & -0.6 & -0.7 & -0.8 & -0.9 & -0.9 & -1.0 \\ \text { Labor Effort } & -0.0 & -0.1 & -0.1 & -0.1 & -0.1 & -0.1 & -0.2 & -0.2 & -0.2 & -0.2 & -0.2\end{array}$

Long-Run Effects of Different Price Markups and Wage Markups

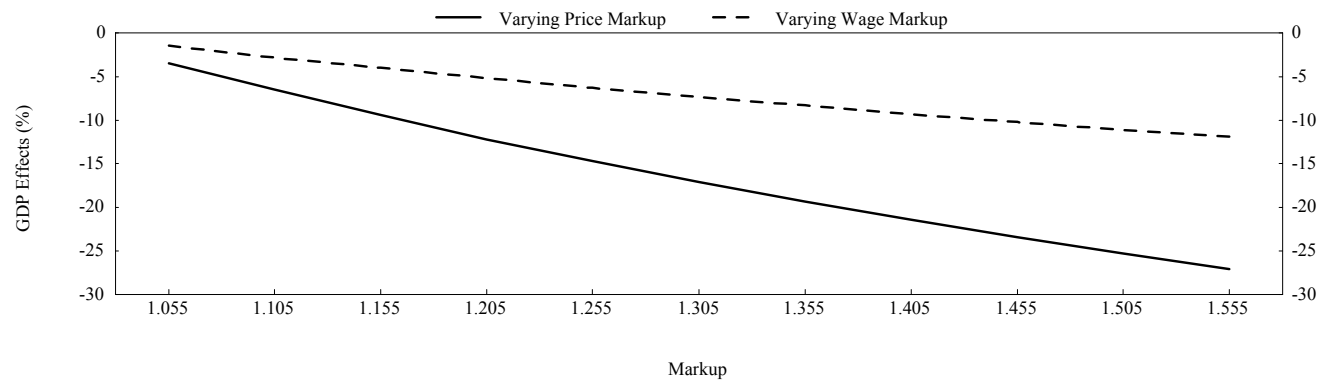

Sacrifice Ratios for Home Country Under Different Markups

$\begin{array}{llllllllllll}1.005 & 1.055 & 1.105 & 1.155 & 1.205 & 1.255 & 1.305 & 1.355 & 1.405 & 1.455 & 1.505 & 1.555\end{array}$

\begin{tabular}{|c|c|c|c|c|c|c|c|c|c|c|c|}
\hline $\begin{array}{l}\text { Sacrifice Ratio } \\
\text { (Varying Price Markup) }\end{array}$ & 0.1 & 0.3 & 0.4 & 0.6 & 0.7 & 0.9 & 1.1 & 1.2 & 1.4 & 1.5 & 1.7 \\
\hline $\begin{array}{l}\text { Sacrifice Ratio } \\
\text { (Varying Wage Markup) }\end{array}$ & 0.1 & 0.5 & 0.7 & 0.9 & 1.0 & 1.1 & 1.2 & 1.3 & 1.4 & 1.5 & 1.6 \\
\hline
\end{tabular}


Figure 9: Effects of Different Price and Wage Markups on Sacrifice Ratios and LongRun Economic Activity (BASE-CASE PARAMETERS WITH REDUCED INTERTEMPORAL ELASTICITY OF SUBSTITUTION $1 / \sigma=1 / 0.99$ )

\section{Long-Run Effects of Different Price Markups and Wage Markups}

$$
\begin{array}{lllllllllll}
1.055 & 1.105 & 1.155 & 1.205 & 1.255 & 1.305 & 1.355 & 1.405 & 1.455 & 1.505 & 1.555
\end{array}
$$

Home Country Long-run Effects of Higher Price Markups (In percent)

\begin{tabular}{|c|c|c|c|c|c|c|c|c|c|c|c|}
\hline SDP & -3.2 & -6.1 & -8.8 & -11.3 & -13.6 & -15.8 & -17.9 & -19.9 & -21.7 & -23.4 & -25.1 \\
\hline tion & -1 & -3.2 & -4.8 & -6.3 & -7.9 & -9.4 & -10.8 & -12.2 & -13.6 & -14.9 & -16.3 \\
\hline vestment & -6 & -13.0 & -18.4 & -23.4 & -27.8 & -31.8 & -35.5 & -38 & -4 & -44.7 & -47 \\
\hline Labor Effort & -1 . & -3.3 & -4.7 & -6 . & -7.4 & -8.6 & -9.7 & -10.8 & -1 & -12.8 & 7 \\
\hline eal Exchange Rate & -1.7 & -3.4 & -4.8 & -6.2 & -7.5 & -8.7 & -9.9 & -10.9 & -11.9 & -12.9 & -13.8 \\
\hline
\end{tabular}

(- appreciation)

Spillover Effects on Foreign Country of Higher Price Markups in Home Country (In percent)

\begin{tabular}{|c|c|c|c|c|c|c|c|c|c|c|c|}
\hline GDP & -0.2 & -0.3 & -0.5 & -0.6 & -0.7 & -0.9 & -1.0 & -1.1 & -1.2 & -1.2 & -1.3 \\
\hline Consumption & -0.3 & -0.7 & -0.9 & -1.2 & -1.4 & -1.7 & -1.9 & -2.1 & -2.3 & -2.4 & -2.6 \\
\hline Investment & -0.1 & -0.2 & -0.3 & -0.4 & -0.5 & -0.6 & -0.7 & -0.8 & -0.8 & -0.9 & -0.9 \\
\hline Labor Effort & 0.0 & 0.1 & 0.1 & 0.1 & 0.2 & 0.2 & 0.2 & 0.2 & 0.2 & 0.3 & 0.3 \\
\hline
\end{tabular}

Home Country Long-run Effects of Higher Wage Markups (In percent)

$\begin{array}{lccccccccccc}\text { GDP } & -1.2 & -2.3 & -3.4 & -4.4 & -5.3 & -6.2 & -7.1 & -7.9 & -8.7 & -9.5 & -10.2 \\ \text { Consumption } & -1.1 & -2.2 & -3.1 & -4.1 & -5.0 & -5.8 & -6.6 & -7.4 & -8.1 & -8.8 & -9.5 \\ \text { Investment } & -1.2 & -2.3 & -3.4 & -4.4 & -5.4 & -6.3 & -7.1 & -8.0 & -8.8 & -9.5 & -10.2 \\ \text { Labor Effort } & -1.2 & -2.4 & -3.5 & -4.5 & -5.5 & -6.4 & -7.3 & -8.2 & -9.0 & -9.8 & -10.5 \\ \text { Real Exchange Rate } & -0.4 & -0.8 & -1.1 & -1.5 & -1.8 & -2.1 & -2.4 & -2.7 & -3.0 & -3.2 & -3.5 \\ \text { (- appreciation) } & & & & & & & & & & & \end{array}$

Spillover Effects on Foreign Country of Higher Wage Markups in Home Country (In percent)

\begin{tabular}{|c|c|c|c|c|c|c|c|c|c|c|c|}
\hline GDP & -0.0 & -0.1 & -0.1 & -0.1 & -0.2 & -0.2 & -0.2 & -0.3 & -0.3 & -0.3 & -0.4 \\
\hline Consumption & -0.1 & -0.2 & -0.2 & -0.3 & -0.4 & -0.4 & -0.5 & -0.5 & -0.6 & -0.6 & \\
\hline Investment & -0.0 & -0.1 & -0.1 & -0.1 & -0.1 & -0.2 & -0.2 & -0.2 & -0.2 & -0.2 & \\
\hline Labor Effort & 0.0 & 0.0 & 0.0 & 0.0 & 0.0 & 0.0 & 0.0 & 0.1 & 0.1 & 0.1 & \\
\hline
\end{tabular}

Long-Run Effects of Different Price Markups and Wage Markups

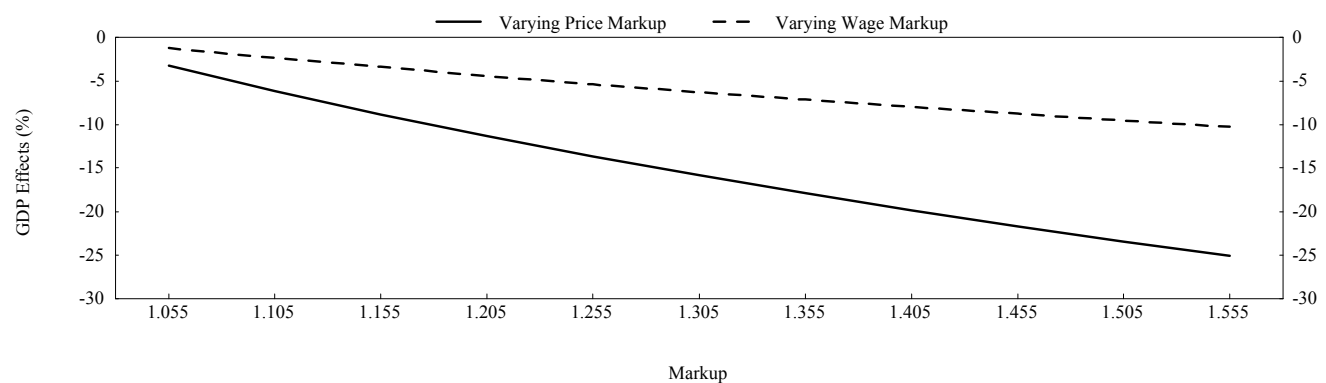

Sacrifice Ratios for Home Country Under Different Markups

\begin{tabular}{|c|c|c|c|c|c|c|c|c|c|c|c|c|}
\hline & 005 & 1.055 & 1.105 & 1.155 & 1.205 & 1.255 & 1.305 & 1.355 & 1.405 & 1.455 & 1.505 & 1.555 \\
\hline $\begin{array}{l}\text { Sacrifice Ratio } \\
\text { (Varying Price Markup) }\end{array}$ & 0.2 & 0.3 & 0.5 & 0.6 & 0.8 & 1.0 & 1.2 & 1.4 & 1.6 & 1.8 & 2.0 & 2.2 \\
\hline $\begin{array}{l}\text { Sacrifice Ratio } \\
\text { (Varying Wage Markup) }\end{array}$ & 0.2 & 0.6 & 0.8 & 1.0 & 1.2 & 1.3 & 1.4 & 1.5 & 1.6 & 1.7 & 1.8 & 1.9 \\
\hline
\end{tabular}


Table 5: Model Estimates of the Long-Run Effects of More Competition-Friendly Policies in the Euro Area (Percent Deviations from Baseline)

\begin{tabular}{|l|c|l|l|}
\hline & Product Market Reforms & Labor Market Reforms & Both Reforms \\
\hline & & & \\
\hline Euro area: & & & \\
\hline GDP & 8.6 & 3.5 & 12.4 \\
\hline Welfare (Consumption Equivalent) & 1.9 & 0.9 & 2.4 \\
\hline Consumption & 4.9 & 3.3 & 8.3 \\
\hline Investment & 17.0 & 3.5 & 21.2 \\
\hline Labor Effort & 4.5 & 3.6 & 8.3 \\
\hline Real Exchange Rate & 4.2 & 1.1 & 5.3 \\
\hline & & & \\
\hline Rest of world: & & & \\
\hline GDP & 0.7 & 0.2 & 0.8 \\
\hline Welfare (Consumption Equivalent) & 0.9 & 0.3 & 1.2 \\
\hline Consumption & 1.0 & 0.3 & 1.3 \\
\hline Investment & 0.5 & 0.1 & 0.7 \\
\hline Labor Effort & 0.1 & 0.0 & 0.2 \\
\hline
\end{tabular}

Table 6: Model Estimates of the Sacrifice Ratio under More Competition-Friendly Policies in the Euro Area (Percent Deviations from Baseline)

\begin{tabular}{|l|c|l|l|}
\hline & Labor Market Reforms & Product Market Reforms & Both Reforms \\
\hline & & & \\
\hline Sacrifice Ratio & $2.0 \Longrightarrow 1.7$ & $2.0 \Longrightarrow 1.7$ & $2.0 \Longrightarrow 1.4$ \\
\hline
\end{tabular}

